OPEN ACCESS

Edited by:

Jing-Yan Han,

Peking University, China

Reviewed by:

Stefano Tarantini,

University of Oklahoma Health

Sciences Center, United States

Ke-Wu Zeng,

Peking University, China

*Correspondence:

Jiangang Shen

shenjg@hkucc.hku.hk

${ }^{\dagger}$ These authors have contributed equally to this work

Specialty section: This article was submitted to

Vascular Physiology, a section of the journal

Frontiers in Physiology

Received: 20 January 2020 Accepted: 08 April 2020

Published: 19 May 2020

Citation:

Chen S, Chen H, Du Q and

Shen J (2020) Targeting

Myeloperoxidase (MPO) Mediated Oxidative Stress and Inflammation for Reducing Brain Ischemia Injury:

Potential Application of Natural Compounds. Front. Physiol. 11:433.

doi: 10.3389/fphys.2020.00433

\section{Targeting Myeloperoxidase (MPO) Mediated Oxidative Stress and Inflammation for Reducing Brain Ischemia Injury: Potential Application of Natural Compounds}

\author{
Shuang Chen ${ }^{1 \dagger}$, Hansen Chen ${ }^{1,2 \dagger}$, Qiaohui Du ${ }^{1}$ and Jiangang Shen ${ }^{1,2 *}$ \\ ${ }^{1}$ School of Chinese Medicine, The University of Hong Kong, Pok Fu Lam, Hong Kong, ${ }^{2}$ Shenzhen Institute of Research \\ and Innovation, The University of Hong Kong, Shenzhen, China
}

Oxidative stress and inflammation are two critical pathological processes of cerebral ischemia-reperfusion injury. Myeloperoxidase (MPO) is a critical inflammatory enzyme and therapeutic target triggering both oxidative stress and neuroinflammation in the pathological process of cerebral ischemia-reperfusion injury. MPO is presented in infiltrated neutrophils, activated microglial cells, neurons, and astrocytes in the ischemic brain. Activation of MPO can catalyze the reaction of chloride and $\mathrm{H}_{2} \mathrm{O}_{2}$ to produce $\mathrm{HOCl}$. MPO also mediates oxidative stress by promoting the production of reactive oxygen species (ROS) and reactive nitrogen species (RNS), modulating the polarization and inflammation-related signaling pathways in microglia and neutrophils. MPO can be a therapeutic target for attenuating oxidative damage and neuroinflammation in ischemic stroke. Targeting MPO with inhibitors or gene deficiency significantly reduced brain infarction and improved neurological outcomes. This article discusses the important roles of MPO in mediating oxidative stress and neuroinflammation during cerebral ischemia-reperfusion injury and reviews the current understanding of the underlying mechanisms. Furthermore, we summarize the active compounds from medicinal herbs with potential as MPO inhibitors for anti-oxidative stress and anti-inflammation to attenuate cerebral ischemia-reperfusion injury, and as adjunct therapeutic agents for extending the window of thrombolytic treatment. We highlight that targeting MPO could be a promising strategy for alleviating ischemic brain injury, which merits further translational study.

Keywords: ischemic stroke, myeloperoxidase, natural compound, neuroinflammation, oxidative stress

\section{INTRODUCTION}

Stroke is a major human disease burden leading to death and life-long disability. Tissue plasminogen activator (t-PA) is the only therapeutic drug for ischemic stroke approved by the US Food and Drug Administration (FDA). However, t-PA has a restricted time window of $4.5 \mathrm{~h}$, and delayed t-PA infusion increases the risk of hemorrhagic transformation and carries high mortality (Wardlaw et al., 2012). Delayed t-PA infusion mediates cerebral ischemia-reperfusion injury. Thus, 
it is important to develop novel therapy or/and combination agents for thrombolytic therapy to prevent and attenuate cerebral ischemia-reperfusion injury in ischemic stroke treatment.

The brain has a large oxygen consumption due to high a metabolic rate, and the sudden arrest of oxygen triggers oxidative stress, which plays an important role in mediating cerebral ischemia-reperfusion injury (Allen and Bayraktutan, 2009; Rodrigo et al., 2013). Recanalization with delayed thrombolytic treatment further produces reactive oxygen/nitrogen species (ROS/RNS) such as superoxide $\left(\mathrm{O}^{-}\right)$, hydrogen peroxide $\left(\mathrm{H}_{2} \mathrm{O}_{2}\right)$, hypochlorous acid ( $\left.\mathrm{HOCl}\right)$, nitric oxide (NO), and peroxynitrite $\left(\mathrm{ONOO}^{-}\right)$. Antioxidant therapies such as edaravone, NXY-059, and allopurinol improved outcomes of acute ischemic stroke patients (Lees et al., 2006; Muir et al., 2008; Nakase et al., 2011). Many other antioxidants also have the potential to reduce cerebral ischemia injury. For example, nicotinamide adenine dinucleotide $(\mathrm{NAD}+)$ is a crucial player in modulating cellular energy metabolism and oxidative damage (Kiss et al., 2019a,b). Cellular NAD + level was significantly decreased during cerebral ischemia/reperfusion injury and exogenous NAD + supplementation prevented oxidative stress and increased the production of ATP, subsequently reducing cerebral ischemia/reperfusion injury (Ying et al., 2007; Huang Q. et al., 2018). Recently, the roles of RNS, including nitrogen monoxide, nitrogen dioxide, and peroxynitrite, etc., have drawn significant attention from the scientific community. RNS could activate multiple cellular signaling pathways involved in the BBB disruption, infarction enlargement and apoptotic cell death in cerebral ischemia-reperfusion injury (Chen et al., 2013). Matrix metalloproteinase (MMP), a classic proteolytic enzyme, is one of the critical molecular targets of RNS in mediating neuroinflammation and hemorrhagic transformation during cerebral ischemia-reperfusion injury (Gasche et al., 1999; Yang Y. et al., 2007; Jickling et al., 2014; Vandooren et al., 2014). MMP-9 is a plasma biomarker for monitoring brain damage and predicting hemorrhagic transformation in ischemic stroke with thrombolytic treatment (Ramos-Fernandez et al., 2011). $N G$-nitro- $L$-arginine methyl ester ( $L$-NAME), a non-selective NOS inhibitor, attenuated the BBB disruption through inhibiting MMP-9 activity in an experimental ischemic stroke animal model (Gursoy-Ozdemir et al., 2004). For decades, we have made great efforts to explore the roles of RNS in mediating BBB disruption and brain injury, and seeking therapeutic targets for drug discovery to attenuate cerebral ischemia-reperfusion injury (Shen et al., 2006; Liu et al., 2009; Gu et al., 2012; Chen et al., 2013 ,2019; Chen H. et al., 2018; Chen H.S. et al., 2015; Fu et al., 2014; Gong et al., 2015; Feng et al., 2018a,b). With the short lifetime of ROS and RNS, it is an extremely challenging task to directly detect ROS/RNS in viable systems. To resolve the problems, we have successfully developed several fluorescent probes with high specificity and sensitivity, and applied the probes to detect peroxynitrite and hypochlorous acid in ischemic stroke rat models (Peng et al., 2014, 2016; Bai et al., 2020). We found that the RNS production aggravates the $\mathrm{BBB}$ disruption and brain damage in cerebral ischemiareperfusion injury through modulating caveolin-1 and MMPs, and targeting RNS/caveolin-1/MMPs signaling cascades could be an important therapeutic strategy to attenuate cerebral ischemia-reperfusion injury (Chen H.S. et al., 2015, Chen H. et al., 2018; Chen H.S. et al., 2018). Treatment of peroxynitrite scavengers attenuated the BBB damage, neuronal cell death and hemorrhagic transformation in different experimental ischemic stroke models (Xu et al., 2013; Chen H. et al., 2018; Chen et al., 2019). In our recent review articles, we highlight peroxynitrite as a therapeutic target for ischemic stroke (Chen et al., 2013, 2016; Chen H.S. et al., 2018).

Inflammatory factors play crucial roles in cerebral ischemiareperfusion injury. At the early stage of cerebral ischemia, the activation of glial cells and infiltration of leukocytes in the injured tissue produced great amounts of pro-inflammatory factors such as TNF- $\alpha$ and IL- $1 \beta$, contributing to BBB damage and hemorrhagic transformation (Jayaraj et al., 2019; Yang C. et al., 2019). The infiltrated neutrophils produced inflammatory factors and aggravated cerebral ischemia-reperfusion injury (Anrather and Iadecola, 2016). Furthermore, reactive and proliferative astrocytes can also disrupt neurovascular cell balance and form a neuroinflammatory environment that is harmful to neurogenesis (Popa-Wagner et al., 2019). Inflammatory factors can activate MMPs, disrupt BBB integrity and worsen brain damage (Rosell et al., 2008; Jickling et al., 2015). The cross-talk between oxidative stress and neuroinflammation in ischemic stroke has been extensively studied (Collino et al., 2006; Chehaibi et al., 2016; Reiche et al., 2019; Yang Q. et al., 2019; Zhou F. et al., 2019). ROS activates various inflammatory factors for inducing neural cell death, disrupting the integrity of the $\mathrm{BBB}$ and enlarging the infarct volume (Crack and Taylor, 2005; Chen H.S. et al., 2018). The production of ROS could aggravate inflammatory responses of the peripheral immunological system and central nervous system by inducing the activation of adhesion molecules and promoting immunocyte infiltration (Granger and Kvietys, 2015; Mizuma and Yenari, 2017; Chen H.S. et al., 2018; Sun et al., 2018). The cross-talk and interaction of ROS/RNS and inflammatory factors could be a critical pathological mechanism and therapeutic target in cerebral ischemia-reperfusion injury. In this review article, we focus on the roles of critical neuroinflammatory enzyme myeloperoxidase (MPO) in mediating oxidative stress and neuroinflammation in cerebral ischemia-reperfusion injury, and summarize recent progress made in bioactive compounds from medicinal plants with antioxidant and anti-inflammation effects for ischemic stroke treatment.

\section{ROLES OF MPO IN ISCHEMIC BRAIN INJURY BY MEDIATING INFLAMMATION AND OXIDATIVE STRESS}

As a heme-containing peroxidase, MPO is highly expressed in multiple inflammatory cells, including neutrophils, activated microglia, monocytes/macrophage, as well as astrocytes and neurons (Nagra et al., 1997; Green et al., 2004; Forghani et al., 2015; Yu et al., 2016). MPO genetic variability appears to increase the risk of ischemic stroke (Manso et al., 2011) and MPO polymorphisms could be associated with the severity of 
brain damage and functional outcomes (Hoy et al., 2003). The increased MPO activity was reported in both experimental stroke animal models and ischemic stroke patients (Barone et al., 1991; Cojocaru et al., 2010; Kong et al., 2014; Jin et al., 2018). The MPO activity in the ischemic cortex was increased early at $6 \mathrm{~h}$ of ischemia onset, peaked at day 5 , and gradually returned to basal level at day 15 in both transient middle cerebral artery occlusion (tMCAO) and permanent MCAO (pMCAO) animal models (Barone et al., 1995). Interestingly, tMCAO had a significantly higher MPO level in the ischemic cortex than the pMCAO model after stroke onset (Barone et al., 1995), indicating that reperfusion could aggravate the activation of MPO for neuroinflammation. The penumbra area had higher MPO expression than the core (Horvath et al., 2018). With the survival of neural cells in the penumbra, this discovery raises the potential therapeutic value to prevent further loss of neural cells in the ischemic brain. Clinical studies yield similar results to animal experiments. The increase of MPO level in plasma was associated with the severity of ischemic brain damage in ischemic stroke patients (Palm et al., 2018; Tziomalos et al., 2019). A functional MRI study reported the positive correlation between MPO expression and infarct volume in ischemic stroke rat brains (Breckwoldt et al., 2008).

The neutrophil activation and degranulation appear to be important mediators for MPO induction and the source of MPO in plasma (Tay et al., 2015). MPO activity derived from neutrophils was peaked at day $1-3$ of stroke onset, whereas MPO from the macrophage/microglia at day 5-7 (Breckwoldt et al., 2008). Neutrophil inhibitory factor (rNIF) was revealed to reduce neutrophil infiltration and infarct size in the ischemic brain (Barone et al., 1995). Neutrophil depletion by using an anti-neutrophil monoclonal antibody (RP3) completely inhibited MPO activity, attenuated brain edema and reduced brain infarction in the ischemic brain after $24 \mathrm{~h}$ of reperfusion (Matsuo et al., 1994). Thus, neutrophil-mediated MPO activation contributes to inflammation and the severity of brain damage during ischemic stroke.

Myeloperoxidase activation also plays crucial roles in oxidative damage in ischemic stroke. N-acetyl lysyltyro sylcysteine amide (KYC, an MPO inhibitor) attenuated oxidative and nitrative damage in the cortex of ischemic core (Yu et al., 2016). Hypochlorous acid ( $\mathrm{HOCl})$ is a crucial cytotoxic factor contributing to the MPO-mediated oxidative injury in ischemic stroke. Activated $\mathrm{MPO}$ induces $\mathrm{HOCl}$ production via catalyzing the reaction of chloride and $\mathrm{H}_{2} \mathrm{O}_{2}$ to induce chlorinative stress (Weiss et al., 1982; Marquez and Dunford, 1994; Yap et al., 2007). HOCl has high diffusivity and oxidative activity to react with lipids, proteins and DNA (Schraufstatter et al., 1990; Prutz, 1996; Panasenko, 1997; Hawkins et al., 2003; Pattison et al., 2003). Activated phagocytes produce $\mathrm{HOCl}$ and recruit inflammatory cells to ischemic brain regions, subsequently mediating the BBB damage (Ullen et al., 2013). Of note, $\mathrm{HOCl}$ itself can exacerbate oxidative stress, promote the translocation of p67(phox) and p47(phox) of $\mathrm{NAD}(\mathrm{P}) \mathrm{H}$ oxidase and mediate the production of superoxide, peroxynitrite and oxidized eNOS dimer in endothelial cells (Xu et al., 2006). Genetic deletion or pharmacological intervention with MPO inhibitors decreased inflammatory cell recruitment, reduced infarct volume, protected the BBB integrity, attenuated neurological deficit and improved survival rates in rodent ischemic stroke model (Forghani et al., 2015; Yu et al., 2016; Kim et al., 2019). The MPO inhibition with 4-aminobenzoic acid hydrazide $(\mathrm{ABAH})$ or MPO deficiency may create a protective environment that decreases inflammatory cell recruitment and increases survival factors to improve functional outcome (Kim et al., 2019). Of note, the MPO inhibitor was more effective when treated at the subacute phase than the acute phase (Forghani et al., 2015). The robust protection of the MPO inhibitor at the subacute phase was consistent with the delayed peak of MPO expression in the ischemic brain (Barone et al., 1995; Breckwoldt et al., 2008). These studies indicate that the MPO-mediated inflammation at the subacute phase could be a critical underlying mechanism contributing to inflammatory brain damage in ischemic stroke. Importantly, MPO inhibition may represent a promising therapeutic target for stroke therapy, particularly even days after the stroke has occurred. Given the reality that most stroke patients cannot make the golden therapeutic window for thrombolysis, further investigations in this aspect may create a novel therapeutic window for improving the outcome of ischemic stroke by reducing the MPO-mediated inflammation and oxidative injury practically. Therefore, the MPO-mediated oxidative stress and neuroinflammation could be critical therapeutic targets for reducing ischemic brain injury.

Furthermore, the MPO-mediated inflammation affects post-stroke neurogenesis. Treatment of 4-ABAH promoted neurogenesis, and induced proliferation of astrocytes in the subventricular zone (SVZ), striatum and cortex (Kim et al., 2016). MPO knockout mice had increased cell proliferation and improved neurological outcomes in post-ischemic stroke rats (Kim et al., 2016). MPO inhibitor KYC decreased the proinflammatory M1 microglial cells and N1 neutrophils, increased the proliferation and differentiation of neuronal stem cells in the ischemic cortex, and protected the exogenous neural stem cells in the ischemic brain (Yu et al., 2018). Therefore, MPO exerts its roles in mediating oxidative stress and inflammation and affects adult neurogenesis in the post-stroke brain.

The MPO-mediated neuroinflammation involves multiple cellular mediators and signaling pathways. PI3K/AKT signaling is one of the cellular signaling pathways in the MPOmediated inflammation during ischemic brain injury. LY294002, a PI3K/AKT inhibitor, abolished the effects of 5-LOX inhibitor Zileuton on inhibiting MPO activity in ischemic brain injury (Tu et al., 2016). LY294002 eliminated the neuroprotective effects of repetitive ischemic preconditioning and its underlying mechanisms could be related to regulating MPO activity (Tu et al., 2015). Except for PI3K/Akt pathway, ADAMTS13 (a disintegrin and metalloprotease with thrombospondin type I repeats-13) can inhibit MPO activity by inactivating the hyperactive ultra-large von Willebrand factor (ULVWF). The MPO activity was enhanced in ADAMTS13-deficient mice but was reduced in VWF-deficient mice under focal cerebral ischemia (Khan et al., 2012). In addition, E-selectin deficient mice showed the reduction of MPO expression in the ischemic brain, possibly via reducing the neutrophil infiltration (Ma et al., 2012). PARP 
also regulates neutrophil infiltration and MPO activity. The PARP inhibitor 3-aminobenzamide (3-AB) largely decreased MPO activity in the ischemic brain (Couturier et al., 2003). Therefore, MPO can be modulated by multiple cellular signaling mechanisms, and MPO is one of the inflammatory factors contributing to the pathology of ischemic stroke through a complex interaction with different cellular signaling molecules, which remains to be further elucidated.

\section{MPO ACTIVATION AND THROMBOLYSIS-INDUCED ISCHEMIC BRAIN INJURY}

Inflammatory factors mediate hemorrhage transformation in ischemic stroke with delayed t-PA treatment. Anti-leukocyte adhesion antibody (anti-CD18) significantly decreased the neurological deficit in a rat ischemic stroke model with t-PA treatment, indicating the potential of targeting leukocytes to extend the therapeutic window of t-PA (Barone et al., 1995). The t-PA treatment increased the MPO level in the plasma of ischemic stroke patients within $1 \mathrm{~h}$ (Dominguez et al., 2010). Notably, MPO activation can trigger oxidative stress and nitrosative stress in the ischemic brain by forming the chlorotyrosine and nitrotyrosine (Yu et al., 2016). We recently reported that nitrotyrosine was associated with MMPs activation, BBB disruption and hemorrhage transformation in ischemic stroke with delayed t-PA treatment (Chen H.S. et al., 2015; Chen H. et al., 2018). The MPO-mediated nitrosative stress could be a potential player in mediating hemorrhagic transformation in ischemic stroke with the delayed t-PA treatment. Notably, treatment of taurine, a $\mathrm{HOCl}$ scavenger, reduced the rates of hemorrhage transformation in experimental ischemic stroke animal model with delayed t-PA treatment (Guan et al., 2011). Hence, the production of $\mathrm{HOCl}$ might be a crucial cytotoxic factor in the MPO-mediated oxidative injury and inflammation. Inhibition of $\mathrm{MPO}-\mathrm{HOCl}$ is a potential therapeutic strategy to minimize hemorrhage transformation, which warrants further investigation.

In summary, recent progress indicates that the study on the MPO-mediated oxidative injury and inflammation not only brings novel insight into understanding the molecular pathology of ischemic brain injury but also represents a promising strategy for drug discovery to target MPO for improving stroke outcome.

\section{MEDICINAL HERBAL COMPOUNDS WITH THE MPO-INHIBITING ACTIVITY SHOWING ANTIOXIDANT, ANTI-INFLAMMATION, AND NEUROPROTECTIVE EFFECTS}

Traditional herbal medicine is an important source for drug discovery due to its long history in clinical practice. Recent studies identified many active compounds with the bioactivities of inhibiting MPO activity, which can be potentially used to attenuate cerebral ischemia-reperfusion injury. Herein, we summarize representative active compounds in the following session. The chemical structures of the compounds refer to Figure 1.

\section{FLAVONOIDS}

Bioflavonoids are well-known antioxidants with neuroprotective properties. Quercetin is a representative flavonoid compound widely existed in medicinal herbs, including Ginkgo biloba leaves and others (Wu X.J. et al., 2019). Quercetin revealed its bioactivities of anti-oxidation, anti-tumor, anti-inflammatory, anti-platelet aggregation, etc. (Mosawy et al., 2013; Li Y. et al., 2016; Chen Z. et al., 2018; Wu L. et al., 2019). Treatment of quercetin $(30,50 \mathrm{mg} / \mathrm{kg})$ attenuated neuronal cell death and reduced infarct size in both global and focal cerebral ischemia animal models (Ahmad et al., 2011; Annapurna et al., 2013; Park et al., 2018). Quercetin inhibited MPO activity and reduced oxidative stress-mediated neural damage in ischemic brain tissues (Annapurna et al., 2013). Rutin is another common and wild distributed flavonoid extracted from medicinal plants, such as Mulberry (Morus alba L.) (Zhao et al., 2015). Pre-treatment with rutin for 21 days (25 mg/kg, daily) significantly attenuated brain damage through up-regulating antioxidant enzymes and inhibiting oxidative stress (Khan et al., 2009). Rutin also revealed to inhibit MMP-9 activity and reduce $\mathrm{BBB}$ disruption (Jang et al., 2014). Interestingly, its neuroprotective and antioxidant effects are related to inhibiting MPO activity (Annapurna et al., 2013).

Eriodictyol is widely distributed in fruits and vegetables, and isolated from the Chinese herb Dracocephalum rupestre. Oral administration of eriodictyol $(1,2,4 \mathrm{mg} / \mathrm{kg})$ exhibited inhibitory effects on MPO expression and inflammation in a permanent ischemic stroke rat model. Eriodictyol treatment down-regulated the expression of TNF- $\alpha$ and iNOS in the ischemic cortex, decreased infarct size, improved motor function, and attenuated the memory deficit in permanent ischemic stroke rats (Ferreira Ede et al., 2016). Eriodictyol-7-O-glucoside (30 mg/kg), also showed neuroprotective effects against cerebral ischemic injury through activating the antioxidant signaling nuclear factor erythroid-2-related factor 2/antioxidant response element (Nrf2/ARE) (Jing et al., 2013).

Isorhamnetin is a typical flavonoid extracted from Hippophae rhamnoides (Li et al., 2015). Treatment of isorhamnetin (5 mg/kg) suppressed MPO activity, attenuated oxidative/nitrosative stress, inhibited inflammatory factors (IL-1 $\beta$, IL-6, and TNF- $\alpha$ ), preserved tight junction proteins and protected the BBB integrity in the acute ischemic stroke model (Zhao et al., 2016). The antiinflammation and anti-oxidative bioactivities of isorhamnetin were also found in the in vitro cultured brain microvascular endothelial cells under oxygen and glucose deprivation (OGD) condition (Li W. et al., 2016).

Biochanin A, an O-methylated natural isoflavonoid, mainly exists in red clover, chickpea or other legumes. Biochanin A revealed various pharmacological functions, including 


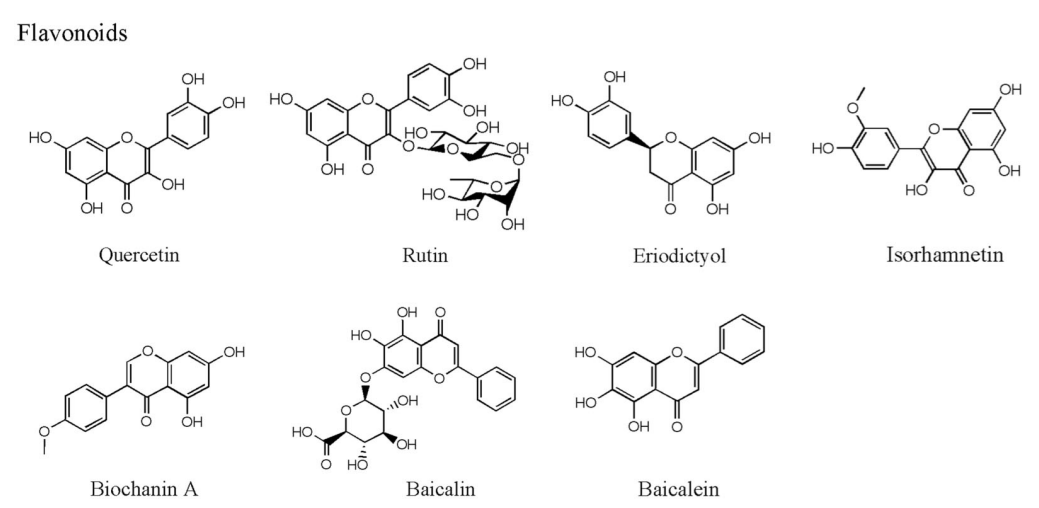

Polyphenol

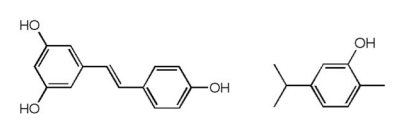<smiles>COc1cc(/C=C/C(=O)CC(=O)/C=C/c2ccc(O)c(OC)c2)ccc1O</smiles>

Resveratrol

Carvacrol

Curcumin<smiles>C=C(C)[C@@H]1CCC(C)=C[C@H]1c1c(O)cc(CCCCC)cc1O</smiles>

Cannabidiol<smiles>COc1cc(/C=C/C(=O)O)ccc1O</smiles><smiles>Oc1ccc(CCC2OC3CCC(O)C(O3)C2O)cc1</smiles>

Rosmarinic acid

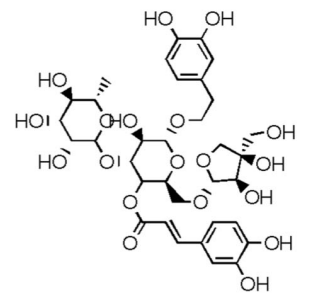

Forsythoside B

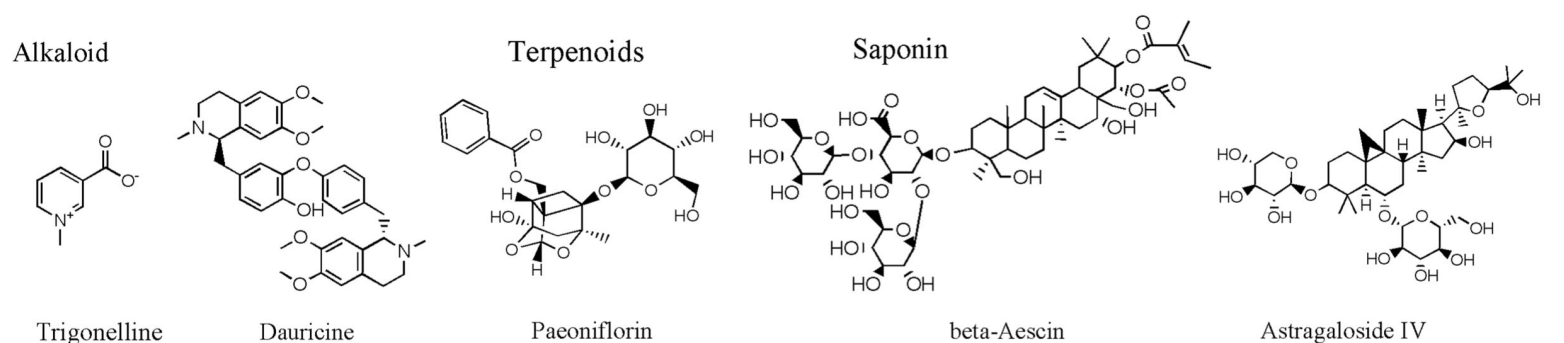

Trigonelline

Dauricine

Paeoniflorin

beta-Aescin

Astragaloside IV

\section{Anthraquinone}<smiles>Cc1coc2c1C(=O)C(=O)c1c-2ccc2c1CCCC2(C)C</smiles>

Tanshinone IIA

\section{Coumarin}

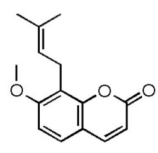

Osthole

Others

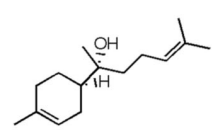

$(-)-\alpha-$ Bisabolol<smiles>CS(=O)CCCCN=C=S</smiles>

Sulforaphane<smiles>C=CCSS(=O)CC=C</smiles>

Allicin

FIGURE 1 | The chemical structures of the natural compounds.

antioxidation, anti-inflammation and anti-tumorigenesis (Mishra et al., 2008; Liu et al., 2016; Guo et al., 2019). Biochanin A suppressed the activity of MPO and down-regulated the expression of IL- $1 \beta$ and TNF- $\alpha$ in acute ischemic brain injury. Treatment with biochanin A $(10,20,40 \mathrm{mg} / \mathrm{kg})$ significantly improved neurological outcomes, reduced infarct volume and brain edema in post-ischemic brain injury (Wang et al., 2015).

Baicalin and its aglycon baicalein are flavonoids extracted from Scutellaria baicalensis, a medicinal plant. Both baicalin and baicalein revealed their neuroprotective effects against cerebral 
ischemia-reperfusion injury and the underlying mechanisms were related to their anti-oxidative stress, anti-apoptotic, antiinflammation and anti-excitotoxicity properties (Tu et al., 2009, 2011a,b; Cui et al., 2010; Xue et al., 2010; Li H.Y. et al., 2012; Li et al., 2017; Liang et al., 2017; Yang et al., 2019). Baicalin (30, $100 \mathrm{mg} / \mathrm{kg}$ ) and baicalein $(50 \mathrm{mg} / \mathrm{kg}$ ) showed to inhibit the MPO activity in the ischemic brain injury (Hwang et al., 2002; Tu et al., 2009). Our recent studies suggest that baicalin reduced infarct size, minimized the $\mathrm{BBB}$ damage and hemorrhage transformation in the experimental ischemic stroke model with delayed t-PA treatment. The underlying mechanisms could be attributed to the direct peroxynitrite-scavenging property (Xu et al., 2013; Chen H. et al., 2018).

\section{POLYPHENOL}

Resveratrol is a polyphenolic compound with a terpenoid structure, mainly found in plants such as grapes, peanuts, mulberry and knotweed. Resveratrol has been used for agingrelated diseases such as cancer, cardiovascular diseases and stroke (Liu et al., 2013, 2018; Dou et al., 2019; Zhou X. et al., 2019). Resveratrol treatment (50 mg/kg) has potent anti-oxidative stress and anti-inflammatory properties and has neuroprotective effects against acute ischemic brain injury (Dou et al., 2019). The neuroprotective mechanisms involve multiple molecular targets such as MMP-9 (Pandey et al., 2015; Wei et al., 2015), NMDA receptor-mediated ERK-CREB signaling pathway (Li W. et al., 2016), JAK2/STAT3 pathway (Hou et al., 2018), neurotransmitters and neuromodulators, excitatory neurotransmitter glutamates, aspartate and neuromodulator d-Serine, etc. ( $\mathrm{Li}$ et al., 2010). The inhibitory effects of resveratrol on MPO activity contributed to its neuroprotective effects (Fang et al., 2015; Lei and Chen, 2018; Lei et al., 2019). Furthermore, resveratrol had the capacity to cross BBB (Wang et al., 2002) and fusogenic liposomes could enhance the delivering efficiency of resveratrol across the BBB (Wiedenhoeft et al., 2019). Carvacrol is a monoterpene phenol and an isomer of thymol commonly found in many aromatic plants including Origanum dictamnus, Origanum vulgare, and Origanum majorana. Carvacrol treatment attenuated neuronal apoptosis, reduced infarct size and improved the neurological outcomes in both adult focal ischemic stroke model and neonatal cerebral hypoxic-ischemic model (Yu et al., 2012; Chen W. et al., 2015). Furthermore, carvacrol (10, 20, $40 \mathrm{mg} / \mathrm{kg}$ ) dose-dependently down-regulated the MPO activity and the expressions of iNOS and COX-2 in the ischemic brain (Li Y. et al., 2016).

Curcumin is a polyphenol in the curry spice turmeric. In ancient Chinese and Indian medicine, curcumin was used to treat various diseases. Curcumin has multiple molecular targets, including transcription factors, growth factors and their receptors (Kunnumakkara et al., 2017). Curcumin has revealed its anti-inflammatory, antioxidant, anti-tumor and cardiovascular protective properties (Menon and Sudheer, 2007; Jiang et al., 2017; Kunnumakkara et al., 2017). The neuroprotective effects of curcumin treatment (150, $200 \mathrm{mg} / \mathrm{kg})$ are related to inhibiting leukocyte infiltration, regulating microglia/macrophage polarization and inflammatory factors production, and inhibiting autophagy against cerebral ischemiareperfusion injury (Liu et al., 2017; Huang L. et al., 2018; Bavarsad et al., 2019). The neuroprotective effects of curcumin are related to inhibition of TLR2/4-NF- $\kappa$ B signaling pathway and reduction of MPO activity in the ischemic brain (Tu et al., 2014).

Cannabidiol (CBD) isolated from Cannabis sativa $L$. (Cannabaceae) (Brand and Zhao, 2017) was reported to increase the cortex blood flow via the serotonergic 5-hydroxytryptamine $1 \mathrm{~A}$ receptor-dependent mechanism (Mishima et al., 2005). CBD treatment $(3 \mathrm{mg} / \mathrm{kg}$ ) attenuated neuroinflammation through inhibiting MPO and HMGB1 in the ischemic brain (Hayakawa et al., 2008). A systematic review supported the neuroprotective effects of CBD in ischemic stroke treatment (England et al., 2015). The neuroprotective mechanisms were also related to inhibition of inflammatory factors NF- $\kappa \mathrm{B}$ and tumor necrosis factor receptor 1 (TNFR1) (Khaksar and Bigdeli, 2017).

Angelica sinen-sis (Oliv.) Diels (AS) and Ligusticum chuanxiong Hort. (LC) are medicinal herbs used for stroke treatment for centuries in China. Ferulic acid (FA) is a bioactive ingredient of AS and LC. FA has revealed to scavenge superoxide radicals and restore vasodilation in spontaneously hypertensive rats (Suzuki et al., 2007). FA treatment at $100 \mathrm{mg} / \mathrm{kg}$ at the beginning of the MCAO stroke model effectively reduced infarct size and improved neurological deficits. The underlying mechanisms were related to inhibiting ICAM-1 and NF- $\kappa \mathrm{B}$, and reducing the infiltrations of the MPO immune-reactive cells (Cheng et al., 2008). Rosmarinic acid (RA) is a natural phenolic compound isolated from Chinese herb Salvia miltiorrhiza (Wu et al., 2015). RA treatment (50 mg/kg) inhibited HMGB1 expression and NF$\kappa \mathrm{B}$ activation, reduced the $\mathrm{BBB}$ permeability, decreased infarct size and alleviated neurological deficits in cerebral ischemiareperfusion injury (Luan et al., 2013). The inhibitory effects of RA on MPO contributed to its neuroprotective effects against ischemic brain injury (Fonteles et al., 2016).

Forsythoside B is an anti-inflammatory compound extracted from the leave of Lamiophlomis rotata Kudo. Even delayed administration of forsythoside $\mathrm{B}$ at $5 \mathrm{~h}$ after reperfusion had a neuroprotective effect. Forsythoside B at the dosage of $20 \mathrm{mg} / \mathrm{kg}$ attenuated brain infarct size, brain edema, and BBB permeability through inhibiting MPO activity and NF- $\kappa \mathrm{B}$ expression against cerebral ischemia/reperfusion injury (Jiang et al., 2010).

\section{ALKALOIDS}

Alkaloids are nitrogen-containing alkaline compounds from medicinal herbs. Trigonelline and dauricine are representative alkaloid with the MPO inhibitory effects. Intraperitoneal injection of trigonelline $(100 \mathrm{mg} / \mathrm{kg})$, a plant alkaloid from fenugreek seeds, inhibited MPO expression, improved the neurological outcomes and alleviated infarct size in ischemic stroke animal models (Pravalika et al., 2019). Dauricine is a BBB permeable bisbenzyl isoquinoline alkaloid extracted from menispermum dauricum DC root. Dauricine treatment at 5 or $10 \mathrm{mg} / \mathrm{kg}$ revealed its neuroprotective effects and the underlying 
mechanisms were associated with the suppression of TNF- $\alpha$, IL$1 \beta$, and ICAM-1 expression and inhibition of PMNs infiltration (Yang X.Y. et al., 2007).

\section{TERPENOIDS}

Paeoniflorin is a natural component derived from Paeonia lactiflora Pall and has anti-inflammatory properties. Intravenous injection of paeoniflorin $(10,15,20 \mathrm{mg} / \mathrm{kg})$ at $10 \mathrm{~min}$ before or $30 \mathrm{~min}$ after MCAO effectively reduced infarct size and ameliorated the neurological deficit via inhibiting PMN infiltration and down-regulating inflammatory factors including TNF- $\alpha$, IL-1 $\beta$, and ICAM-1 (Tang N.Y. et al., 2010).

\section{SAPONINS}

Saponins are widely distributed in various plant species. As the active components in many medicinal herbs, saponins possess diverse biological activities, such as anti-inflammatory, antioxidative stress and neuroprotective effects (Guclu-Ustundag and Mazza, 2007). $\beta$-Aescin is a main bioactive compound isolated from Aesculus hippocastanum, a commonly used medicinal herb for vascular disorders in Traditional Chinese Medicine. Aescin has anti-inflammatory, anti-edema and antioxidation effects (Cheng et al., 2016; Gallelli, 2019). Pretreatment of $\beta$-Aescin $(15,30,60 \mathrm{mg} / \mathrm{kg})$ for 7 days significantly inhibited the MPO activity, reduced the neutrophils migration, lessened infarct sizes, ameliorated neurological deficit in the rat model of MCAO cerebral ischemia-reperfusion injury (Hu et al., 2004). Astragaloside IV, a major component of Astragalus membranaceus, showed its anti-inflammatory property in the focal cerebral ischemia-reperfusion rat model. Treatment of Astragaloside IV (10, $20 \mathrm{mg} / \mathrm{kg})$ at the onset of ischemia or at $12 \mathrm{~h}$ after the reperfusion significantly alleviated infarct volume and neurological deficit. The underlying mechanisms could be related to inhibiting MPO, TNF- $\alpha$, IL$1 \beta$, NF- $\kappa \mathrm{B}$ expression and neutrophil adhesion (Li M. et al., 2012).

\section{POLYSACCHARIDES}

Fucoidan is a sulfated polysaccharide mainly exited in brown algae and brown seaweed. Treatment with fucoidan (80, $160 \mathrm{mg} / \mathrm{kg}$ ) inhibited MPO activity and inflammation-associated cytokines such as IL-1, IL-6, TNF- $\alpha$, and attenuated cerebral ischemia-reperfusion injury (Che et al., 2017).

\section{ANTHRAQUINONE}

Tanshinone IIA is a key bioactive compound in Salvia miltiorrhiza, a commonly used medicinal herb for cardiovascular and cerebral vascular diseases. Tanshinone IIA had neuroprotective effects against focal cerebral I/R injury, and its underlying mechanisms were considered to inhibit the expression of NF-кB, MMP-9 and HMGB1 (Liu et al., 2010; Tang C. et al., 2010). Meanwhile, Tanshinone IIA (25 mg/kg) also revealed to inhibit MPO activity, attenuate macrophage migration inhibitory factor, TNF- $\alpha$ and IL-6, and ameliorate BBB permeability and neurological dysfunction (Chen et al., 2012).

\section{COUMARIN}

Osthole, a natural coumarin derivative, is a bioactive compound from many medicinal herbs such as Angelica pubescens, Cnidium monnieri, and Peucedanum ostruthium. Osthole was reported to improve chronic cerebral hypoperfusion induced cognitive deficits and neuronal damage in the hippocampus (Ji et al., 2010). Osthole revealed its bioactivities of inhibiting MPO, MMP-9, IL-1 $\beta$, and IL-8 for the neuroprotective effects against cerebral ischemic injury (Chao et al., 2010; Mao et al., 2011).

\section{OTHER COMPOUNDS}

Other compounds, like (-)- $\alpha$-bisabolol, sulforaphane, and allicin, also have anti-inflammation effects on inhibiting inflammatory cytokines, including TNF- $\alpha$, IL-1 $\beta$, and IL-6. Those compounds are considered as potential candidates for adjuvant therapy against cerebral ischemia-reperfusion injury. For example, (-)- $\alpha$-bisabolol is an unsaturated sesquiterpene alcohol existed in a variety of plants, such as Matricaria chamomilla, Salvia runcinata and Myoporum crassifolium. (-)- $\alpha$-bisabolol has anti-inflammatory, antioxidant and anti-apoptotic activities (Sampaio et al., 2016). (-)- $\alpha-$ bisabolol (200 mg/kg) showed its neuroprotective effects on reducing infarct size and neurological deficits in a permanent MCAO animal model via inhibiting MPO, TNF- $\alpha$ and iNOS (Fernandes et al., 2019). Sulforaphane, an isothiocyanate occurring in cruciferous vegetables, transcriptionally up-regulated the genes controlling aerobic cells and inhibited oxidative stress and inflammation (Zhang et al., 1992). Intraperitoneally treatment with sulforaphane $(10 \mathrm{mg} / \mathrm{kg})$ at the onset of reperfusion dramatically ameliorated infarct volume, alleviated neurological deficit, and decreased neutrophils infiltration in ischemic brain injury. Sulforaphane also down-regulated the expressions of cleaved caspase-1, IL-1 $\beta$, and IL-18 and inhibited the activation of NLRP3 inflammasome (Yu et al., 2017). Allicin is a major active compound in garlic. Allicin has anti-inflammatory, anti-fungal, antioxidant and anti-tumoral activities (Hunter et al., 2005; Chan et al., 2014; Zhou et al., 2014). Allicin treatment $(50 \mathrm{mg} / \mathrm{kg})$ revealed to reduce TNF- $\alpha$ level and MPO activity, ameliorated infarct size, alleviated brain edema and improved the neurological score in the experimental MCAO ischemic stroke rat models (Zhang et al., 2015). 


\section{PERSPECTIVES}

Targeting MPO and cellular signaling cascades could be a therapeutic strategy to decrease infarct size and improve the neurological outcomes in ischemic stroke treatment (Table 1). As an inflammatory enzyme, MPO activation results in $\mathrm{HOCl}$ production, increases pro-inflammatory cytokine and mediates protein nitration (Nussbaum et al., 2013). MPO is also a highly versatile oxidative enzyme and participates in the pathological process of oxidative and nitrosative stress (Davies et al., 2008). The crosstalk of oxidative stress and inflammation could amplify brain damage in cerebral ischemia-reperfusion injury. The inhibition of MPO could reach two goals for antioxidant and anti-inflammation simultaneously. Importantly, MPO could be an important molecular target for ischemic stroke treatment practically that allows for a broad intervention time window (Kim et al., 2018). Thus, MPO inhibitors have translational values as therapeutic candidates for improving the outcomes of ischemic stroke treatment.

Both oxidative stress and inflammation are crucial pathological mechanisms in the BBB damage and hemorrhagic transformation in ischemic stroke with delayed t-PA treatment. The increased MPO in the plasma was found in ischemic stroke patients after receiving t-PA treatment (Dominguez et al., 2010). Treatment of MPO inhibitor KYC restored the BBB function in experimental autoimmune encephalomyelitis mice (Zhang et al., 2016), showing its potential to prevent inflammatory factors-mediated BBB damage. Thus, MPO-mediated $\mathrm{HOCl}$ production could be a crucial target for promoting anti-oxidative stress and anti-inflammation and preventing hemorrhagic transformation. Developing MPO inhibitors is a promising strategy for expending the golden therapeutic window for $\mathrm{t}-\mathrm{PA}$ treatment.

Compounds from medicinal herbs are important sources for drug discovery. Many of them already show their potential as drug candidates for ischemic stroke treatment. We provide MPO inhibitory compounds in Table 2. Although many studies provide exciting results about the bioactivities of those compounds on MPO inhibition and neuroprotection in different experimental model systems, we should note that most of the studies only examine the activity and expression of MPO in the ischemic brain in vivo. It remains unknown whether those compounds have direct and specific actions of binding MPO or lead molecular modifications to MPO. Since most of the compounds exert antioxidant effects (Table 2), the antioxidant effects would, in turn, inhibit MPO activity in the ischemic brain. It is valuable to examine whether these compounds could directly inhibit MPO or not. On the other hand, the pharmacological effects of those natural compounds may also be due to modulating multiple targets and signaling pathways in the ischemic brain, rather than just a single target (Chen et al., 2017). The onecompound-multi-target pattern may allow for inhibiting MPO activity as well as other inflammatory factors. Furthermore, we would remark that those neuroprotective compounds may serve to reduce the complications of delayed t-PA treatment and extend the therapeutic time window of t-PA. Studies seldomly provide information on pharmacokinetic and pharmacodynamic 
TABLE 2 | Natural compound inhibiting MPO for protecting ischemic stroke injury.

\begin{tabular}{|c|c|c|c|c|c|c|c|}
\hline Compound & $\begin{array}{l}\text { Representative } \\
\text { sources }\end{array}$ & $\begin{array}{l}\text { Experimental } \\
\text { model }\end{array}$ & $\begin{array}{l}\text { Treatment } \\
\text { time point and path }\end{array}$ & Dosage & targets & Major results & References \\
\hline Quercetin & Ruta graveolens $\mathrm{L}$. & $\begin{array}{l}\text { Global cerebral } \\
\text { ischemia } \\
\text { (I } 30 \mathrm{~min} / \mathrm{R} 4 \mathrm{~h} \text { ) }\end{array}$ & $\begin{array}{l}10 \text { min before reperfusion } \\
\text { (not given) }\end{array}$ & $50 \mathrm{mg} / \mathrm{kg}$ & MDA, MPO, SOD, CAT & infarct volume & Annapurna et al., 2013 \\
\hline Rutin & Ruta graveolens $\mathrm{L}$. & $\begin{array}{l}\text { Global cerebral } \\
\text { ischemia } \\
\text { (I } 30 \mathrm{~min} / \mathrm{R} 4 \mathrm{~h} \text { ) }\end{array}$ & $\begin{array}{l}10 \text { min before reperfusion } \\
\text { (not given) }\end{array}$ & $10 \mathrm{mg} / \mathrm{kg}$ & MDA, MPO, SOD, CAT & infarct volume & Annapurna et al., 2013 \\
\hline Eriodictyol & $\begin{array}{l}\text { Dracocephalum } \\
\text { rupestre and citrus } \\
\text { fruits }\end{array}$ & PMCAO & $\begin{array}{l}30 \text { mins before and } 2 \mathrm{~h} \\
\text { after pMCAO and lasting } \\
\text { for } 5 \text { days. I.G. }\end{array}$ & $4 \mathrm{mg} / \mathrm{kg}$ & MPO, TNF- $\alpha$, iNOS & $\begin{array}{l}\text { neurological deficit, infarct } \\
\text { volume, Open-field test, } \\
\text { Y-maze test, Passive avoidance } \\
\text { test }\end{array}$ & Ferreira Ede et al., 2016 \\
\hline Isorhamnetin & $\begin{array}{l}\text { Hippophae rhamnoides } \\
\text { L., Oenanthe javanica } \\
\text { and Ginkgo biloba L., }\end{array}$ & $\begin{array}{l}\text { tMCAO } \\
(\text { ( } 11 \mathrm{~h} / \mathrm{R} 48 \mathrm{~h})\end{array}$ & $\begin{array}{l}\text { Onset and } 24 \mathrm{~h} \text { of } \\
\text { reperfusion. I.P. }\end{array}$ & $5 \mathrm{mg} / \mathrm{kg}$ & $\begin{array}{l}\text { Caspase-3, occluding, } \\
\text { ZO-1, claudin-5, AQP4, } \\
\text { MDA, iNOS, Nrf2, HO-1, } \\
\text { 3-NT, NMDA NR1, MPO, } \\
\text { TNF- } \alpha, \text { IL-1 } \beta, \text { IL-6 }\end{array}$ & $\begin{array}{l}\text { neurological deficit, infarct } \\
\text { volume, brain edema, BBB } \\
\text { permeability }\end{array}$ & Zhao et al., 2016 \\
\hline Biochanin A & $\begin{array}{l}\text { red clover, chickpea or } \\
\text { other legumes }\end{array}$ & $\begin{array}{l}\text { tMCAO } \\
\text { (I } 2 \mathrm{~h} / \mathrm{R} 24 \mathrm{~h})\end{array}$ & $\begin{array}{l}\text { Lasting for } 14 \text { days before } \\
\text { MCAO. I.P. }\end{array}$ & $20,40 \mathrm{mg} / \mathrm{kg}$ & MPO, TNF- $\alpha$, IL-1 $\beta, p 38$ & $\begin{array}{l}\text { neurological deficit, infarct } \\
\text { volume, brain edema, }\end{array}$ & Wang et al., 2015 \\
\hline Baicalin & $\begin{array}{l}\text { Scutellaria baicalensis } \\
\text { Georgi }\end{array}$ & $\begin{array}{l}\text { pMCAO } \\
(24 \text { h) }\end{array}$ & 2 and $12 \mathrm{~h}$ after MCAO. I.P. & $30,100 \mathrm{mg} / \mathrm{kg}$ & $\begin{array}{l}\text { MPO, iNOS, COX-2, } \\
\text { Caspase-3 }\end{array}$ & $\begin{array}{l}\text { neurological deficit, infarct } \\
\text { volume }\end{array}$ & Tu et al., 2009 \\
\hline Baicalein & Scutellariae radix & $\begin{array}{l}\text { tMCAO } \\
\text { (I } 2 \mathrm{~h} / \mathrm{R} 22 \mathrm{~h})\end{array}$ & $\begin{array}{l}\text { promptly prior to and } 2 \mathrm{~h} \\
\text { after the reperfusion }\end{array}$ & $50 \mathrm{mg} / \mathrm{kg}$ & MPO & infarct volume & Hwang et al., 2002 \\
\hline Resveratrol & $\begin{array}{l}\text { grapes, cranberries and } \\
\text { peanuts }\end{array}$ & $\begin{array}{l}\text { pMCAO } \\
(24 \mathrm{~h})\end{array}$ & Onset of MCAO. I.P. & 100 mg/kg & $\begin{array}{l}\text { IL-1 } \beta \text {, TNF- } \alpha, \text { COX2, MPO, } \\
\text { Akt }\end{array}$ & $\begin{array}{l}\text { neurological deficit, brain } \\
\text { edema }\end{array}$ & Lei and Chen, 2018 \\
\hline Resveratrol & $\begin{array}{l}\text { grapes, cranberries and } \\
\text { peanuts }\end{array}$ & $\begin{array}{l}\text { pMCAO } \\
(24 \mathrm{~h})\end{array}$ & $2 \mathrm{~h}$ after MCAO. I.P. & 100 mg/kg & $\begin{array}{l}\text { MPO, TLR4, NF-кB, p65, } \\
\text { COX-2, MMP-9, TNF- } \alpha \text {, } \\
\text { IL-1 } \beta\end{array}$ & $\begin{array}{l}\text { neurological deficit, infarct } \\
\text { volume, brain edema, BBB } \\
\text { permeability }\end{array}$ & Lei et al., 2019 \\
\hline Resveratrol & $\begin{array}{l}\text { grapes, cranberries and } \\
\text { peanuts }\end{array}$ & $\begin{array}{l}\text { tMCAO } \\
\text { (I } 2 \text { h/R } 24 \text { h) }\end{array}$ & $\begin{array}{l}\text { starting at } 3 \mathrm{~h} \text { after } \\
\text { reperfusion and lasting for } \\
4 \text { days. I.P. }\end{array}$ & $30 \mathrm{mg} / \mathrm{kg}$ & $\begin{array}{l}\text { Caspase-3, Bcl2, Bax, } \\
\text { MPO, TNF- } \alpha\end{array}$ & $\begin{array}{l}\text { neurological deficit, infarct } \\
\text { volume, brain edema }\end{array}$ & Fang et al., 2015 \\
\hline Carvacrol & Lamiaceae & $\begin{array}{l}\text { tMCAO } \\
\text { (I } 2 \text { h/R } 24 \text { h) }\end{array}$ & $\begin{array}{l}1 \text { and } 12 \mathrm{~h} \text { after the onset } \\
\text { of MCAO. I.P. }\end{array}$ & $\begin{array}{l}10,20 \\
40 \mathrm{mg} / \mathrm{kg}\end{array}$ & $\begin{array}{l}\text { MPO, TNF- } \alpha, \text { IL-1 } \beta \text {, iNOS, } \\
\text { COX-2, SOD, MDA, NF-kB } \\
\text { p65 }\end{array}$ & Not detected & Li Y. et al., 2016 \\
\hline Curcumin & $\begin{array}{l}\text { Curcuma aromatica } \\
\text { Salisb. }\end{array}$ & $\begin{array}{l}\text { pMCAO } \\
(24 \mathrm{~h})\end{array}$ & 2 and $12 \mathrm{~h}$ after MCAO. I.P. & $10,50 \mathrm{mg} / \mathrm{kg}$ & $\begin{array}{l}\text { MPO, TLR2, TLR4, NF-kB } \\
\text { p65, TNF- } \alpha, \text { IL-1 } \beta\end{array}$ & $\begin{array}{l}\text { neurological deficit, infarct } \\
\text { volume, brain edema, } \\
\text { Neutrophil Infiltration }\end{array}$ & Tu et al., 2014 \\
\hline Cannabidiol & Marijuana & $\begin{array}{l}\text { tMCAO } \\
\text { (I } 4 \mathrm{~h} / \mathrm{R} 24 \mathrm{~h})\end{array}$ & $\begin{array}{l}\text { immediately before and } 3 \mathrm{~h} \\
\text { after MCAO. I.P. }\end{array}$ & $3 \mathrm{mg} / \mathrm{kg}$ & MPO, HMGB1 & $\begin{array}{l}\text { neurological deficit, infarct } \\
\text { volume, Rota-rod test }\end{array}$ & Hayakawa et al., 2008 \\
\hline Allicin & garlic & $\begin{array}{l}\text { tMCAO } \\
\text { (I } 1.5 \mathrm{~h} / \mathrm{R} 24 \mathrm{~h})\end{array}$ & $\begin{array}{l}3 \mathrm{~h} \text { after reperfusion daily } \\
\text { for five consecutive days. } \\
\text { I.P. }\end{array}$ & $50 \mathrm{mg} / \mathrm{kg}$ & MPO, Caspase-3, TNF- $\alpha$ & $\begin{array}{l}\text { neurological deficit, infarct } \\
\text { volume, brain edema }\end{array}$ & Zhang et al., 2015 \\
\hline
\end{tabular}


TABLE 2 | Continued

\begin{tabular}{|c|c|c|c|c|c|c|c|}
\hline Compound & $\begin{array}{l}\text { Representative } \\
\text { sources }\end{array}$ & $\begin{array}{l}\text { Experimental } \\
\text { model }\end{array}$ & $\begin{array}{l}\text { Treatment } \\
\text { time point and path }\end{array}$ & Dosage & Targets & Major results & References \\
\hline Ferulic acid & $\begin{array}{l}\text { Angelica sinensis and } \\
\text { Ligusticum chuanxiong }\end{array}$ & $\begin{array}{l}\text { tMCAO } \\
\text { (1 } 1.5 \mathrm{~h} / \mathrm{R} 24 \mathrm{~h})\end{array}$ & Onset of MCAO, I.V. & 100 mg/kg & ICAM-1, MPO, NF-кB & $\begin{array}{l}\text { neurological deficit, infarct } \\
\text { volume }\end{array}$ & Cheng et al., 2008 \\
\hline Ferulic acid & $\begin{array}{l}\text { Angelica sinensis and } \\
\text { Ligusticum chuanxiong }\end{array}$ & $\begin{array}{l}\text { tMCAO } \\
(11.5 \mathrm{~h} / \mathrm{R} 2 \mathrm{~h})\end{array}$ & Onset of MCAO, I.V. & 100 mg/kg & ICAM-1, MPO, NF-кB & Not detected & Cheng et al., 2008 \\
\hline Rosmarinic acid & Rosmarinus officinalis & pMCAO & $\begin{array}{l}30 \text { mins before and } 1 \mathrm{~h} \\
\text { after pMCAO and lasting } \\
\text { for } 5 \text { days. I.P. }\end{array}$ & $20 \mathrm{mg} / \mathrm{kg}$ & MPO, SYP, BDNF & $\begin{array}{l}\text { neurological deficit, infarct } \\
\text { volume, Open-field test, } \\
\text { Y-maze test, Object recognition } \\
\text { test, Water maze test }\end{array}$ & Fonteles et al., 2016 \\
\hline Forsythoside B & $\begin{array}{l}\text { Lamiophlomis rotata } \\
\text { Kudo }\end{array}$ & $\begin{array}{l}\text { tMCAO } \\
\text { (l } 1 \mathrm{~h} / \mathrm{R} 23 \mathrm{~h})\end{array}$ & $\begin{array}{l}3,5,7 \mathrm{~h} \text { after reperfusion. } \\
\text { I.V. }\end{array}$ & $20 \mathrm{mg} / \mathrm{kg}$ & NF-кB, ІкB- $\alpha$, MPO & $\begin{array}{l}\text { neurological deficit, infarct } \\
\text { volume, brain edema, BBB } \\
\text { permeability }\end{array}$ & Jiang et al., 2010 \\
\hline Trigonelline & Fenugreek seeds & $\begin{array}{l}\text { tMCAO } \\
(\text { ( } 1.5 \mathrm{~h} / \mathrm{R} 24 \mathrm{~h})\end{array}$ & $\begin{array}{l}30 \text { min before MCAO, or } \\
\text { immediately after MCAO or } \\
1 \mathrm{~h} \text { post MCAO. I.P. }\end{array}$ & 100 mg/kg & MPO, GSH, MDA, Nitrite & $\begin{array}{l}\text { neurological deficit, infarct } \\
\text { volume }\end{array}$ & Pravalika et al., 2019 \\
\hline Dauricine & $\begin{array}{l}\text { Menispermum } \\
\text { dauricum DC }\end{array}$ & $\begin{array}{l}\text { tMCAO } \\
\text { (l } 1 \mathrm{~h} / \mathrm{R} 24 \mathrm{~h})\end{array}$ & $1 \mathrm{~h}$ after MCAO. I.P. & $5,10 \mathrm{mg} / \mathrm{kg}$ & $\begin{array}{l}\text { MPO, ICAM-1, TNF- } \alpha \\
\text { IL-1 } \beta\end{array}$ & $\begin{array}{l}\text { Polymorphic neutrophils } \\
\text { Infiltration }\end{array}$ & Yang X.Y. et al., 2007 \\
\hline Paeoniflorin & paeonia lactiflora Pall & $\begin{array}{l}\text { tMCAO } \\
(\text { ( } 1.5 \mathrm{~h} / \mathrm{R} 24 \mathrm{~h})\end{array}$ & 10 min before MCAO. I.V & $20 \mathrm{mg} / \mathrm{kg}$ & $\begin{array}{l}\text { MPO, TNF- } \alpha, \text { IL-1 } \beta \text {, ED1, } \\
\text { ICAM-1, Apoptosis }\end{array}$ & $\begin{array}{l}\text { neurological deficit, infarct } \\
\text { volume }\end{array}$ & Tang N.Y. et al., 2010 \\
\hline$\beta$-Aescin & $\begin{array}{l}\text { Aesculus } \\
\text { hippocastanum }\end{array}$ & $\begin{array}{l}\text { tMCAO } \\
\text { (I } 2 \text { h/R } 24 \text { h) }\end{array}$ & $\begin{array}{l}\text { Lasting for } 7 \text { days before } \\
\text { MCAO. I.P. }\end{array}$ & $60 \mathrm{mg} / \mathrm{kg}$ & ICAM-1, E-selectin, MPO & $\begin{array}{l}\text { neurological deficit, infarct } \\
\text { volume, Neutrophil Infiltration }\end{array}$ & Hu et al., 2004 \\
\hline Astragaloside IV & $\begin{array}{l}\text { astragalus } \\
\text { membranaceus }\end{array}$ & $\begin{array}{l}\text { tMCAO } \\
(\text { ( } 1.5 \mathrm{~h} / \mathrm{R} 24 \mathrm{~h})\end{array}$ & $\begin{array}{l}\text { immediately and } 12 \mathrm{~h} \text { after } \\
\text { the onset of reperfusion. I.P. }\end{array}$ & $10,20 \mathrm{mg} / \mathrm{kg}$ & $\begin{array}{l}\text { MPO, TNF- } \alpha, \text { L- } 1 \beta \text {, } \\
\text { ICAM- } 1, \text { NF-kB }\end{array}$ & $\begin{array}{l}\text { neurological deficit, infarct } \\
\text { volume }\end{array}$ & Li M. et al., 2012 \\
\hline Fucoidan & brown algae & $\begin{array}{l}\text { tMCAO } \\
\text { (I 2h/R24 h) }\end{array}$ & 7 days before MCAO, I.P. & $80,160 \mathrm{mg} / \mathrm{kg}$ & $\begin{array}{l}\text { IL-1 } 1 \beta, \text { IL-6, MPO, TNF- } \alpha \text {, } \\
\text { MDA, SOD, p-53, Bax, } \\
\text { Bcl2, p-ERK, JNK, p38 }\end{array}$ & $\begin{array}{l}\text { neurological deficit, infarct } \\
\text { volume }\end{array}$ & Che et al., 2017 \\
\hline Tanshinone IIA & Danshen & $\begin{array}{l}\text { tMCAO } \\
\text { (I } 2 \mathrm{~h} / \mathrm{R} 24 \mathrm{~h})\end{array}$ & 10 min after MCAO, I.P. & $25 \mathrm{mg} / \mathrm{kg}$ & MPO, MIF, TNF- $\alpha$, IL-6 & $\begin{array}{l}\text { neurological deficit, infarct } \\
\text { volume, brain edema }\end{array}$ & Chen et al., 2012 \\
\hline Osthole & $\begin{array}{l}\text { Angelica pubescens, } \\
\text { Cnidium monnieri and } \\
\text { Peucedanum } \\
\text { ostruthium }\end{array}$ & $\begin{array}{l}\text { tMCAO } \\
\text { (I } 2 \text { h/R } 24 \text { h) }\end{array}$ & 30 min before MCAO, I.P. & $20,40 \mathrm{mg} / \mathrm{kg}$ & $\begin{array}{l}\text { MDA, GSH, MPO, IL-1 } \beta \text {, } \\
\text { IL-8 }\end{array}$ & $\begin{array}{l}\text { neurological deficit, infarct } \\
\text { volume, brain edema }\end{array}$ & Chao et al., 2010 \\
\hline (-)- $\alpha$-bisabolol & Matricaria chamomilla & PMCAO & $\begin{array}{l}1 \text { day before and } 1 \mathrm{~h} \text { after } \\
\text { pMCAO and lasting for } \\
5 \text { days. I.G. }\end{array}$ & 200 mg/kg & MPO, TNF- $\alpha$, iNOS & $\begin{array}{l}\text { neurological deficit, infarct } \\
\text { volume, Open-field test, } \\
\text { Y-maze test, Passive avoidance } \\
\text { test, Object recognition test, } \\
\text { Morris water maze }\end{array}$ & Fernandes et al., 2019 \\
\hline Sulforaphane & cruciferous vegetables & $\begin{array}{l}\text { tMCAO } \\
(\mathrm{l} 1 \mathrm{~h} / \mathrm{R} 24 \mathrm{~h})\end{array}$ & $\begin{array}{l}\text { the beginning of reper- } \\
\text { fusion }\end{array}$ & $5,10 \mathrm{mg} / \mathrm{kg}$ & $\begin{array}{l}\text { MPO, Caspase-1, IL-1 } 1 \text {, } \\
\text { IL-18, NLRP3 }\end{array}$ & $\begin{array}{l}\text { neurological deficit, infarct } \\
\text { volume, neutrophils Infiltration }\end{array}$ & Yu et al., 2017 \\
\hline
\end{tabular}


parameters when the pharmacological studies were performed to explore the neuroprotection of a selected compound. For the translational study, we should also pay specific attention to the pharmacokinetics and pharmacodynamics of those compounds and the toxicological evaluation for further development as therapeutic agents. Moreover, the potential interactions of those compounds with t-PA should be examined before being used as combination therapy.

\section{CONCLUSION}

In conclusion, MPO plays a vital role in mediating cerebral ischemia-reperfusion injury via mediating oxidative stress and neuroinflammation. Targeting MPO with natural compounds could be a promising strategy for treating ischemic stroke.

\section{REFERENCES}

Ahmad, A., Khan, M. M., Hoda, M. N., Raza, S. S., Khan, M. B., Javed, H., et al. (2011). Quercetin protects against oxidative stress associated damages in a rat model of transient focal cerebral ischemia and reperfusion. Neurochem. Res. 36, 1360-1371. doi: 10.1007/s11064-011-0458-6

Allen, C. L., and Bayraktutan, U. (2009). Oxidative stress and its role in the pathogenesis of ischaemic stroke. Int. J. Stroke 4, 461-470. doi: 10.1111/j.17474949.2009.00387.x

Annapurna, A., Ansari, M. A., and Manjunath, P. M. (2013). Partial role of multiple pathways in infarct size limiting effect of quercetin and rutin against cerebral ischemia-reperfusion injury in rats. Eur. Rev. Med. Pharmacol. Sci. 17, 491-500.

Anrather, J., and Iadecola, C. (2016). Inflammation and stroke: an overview. Neurotherapeutics 13, 661-670.

Bai, X., Yang, B., Chen, H., Shen, J. G. -, and Yang, D. (2020). HKOCl-4: a rhodolbased yellow fluorescent probe for detection of hypochlorous acid in living cells and tissues. Organ. Chem. Front.

Barone, F. C., Hillegass, L. M., Price, W. J., White, R. F., Lee, E. V., Feuerstein, G. Z., et al. (1991). Polymorphonuclear leukocyte infiltration into cerebral focal ischemic tissue: myeloperoxidase activity assay and histologic verification. J. Neurosci. Res. 29, 336-345. doi: 10.1002/jnr.490290309

Barone, F. C., Hillegass, L. M., Tzimas, M. N., Schmidt, D. B., Foley, J. J., White, R. F., et al. (1995). Time-related changes in myeloperoxidase activity and leukotriene B4 receptor binding reflect leukocyte influx in cerebral focal stroke. Mol. Chem. Neuropathol. 24, 13-30. doi: 10.1007/bf0316 0109

Bavarsad, K., Barreto, G. E., Hadjzadeh, M. A., and Sahebkar, A. (2019). Protective effects of curcumin against ischemia-reperfusion injury in the nervous system. Mol. Neurobiol. 56, 1391-1404. doi: 10.1007/s12035-018-1169-7

Brand, E. J., and Zhao, Z. (2017). Cannabis in chinese medicine: are some traditional indications referenced in ancient literature related to cannabinoids? Front. Pharmacol. 8:108. doi: 10.3389/fphar.2017.00108

Breckwoldt, M. O., Chen, J. W., Stangenberg, L., Aikawa, E., Rodriguez, E., Qiu, S., et al. (2008). Tracking the inflammatory response in stroke in vivo by sensing the enzyme myeloperoxidase. Proc. Natl. Acad. Sci. U.S.A. 105, 1858418589. doi: 10.1073/pnas.0803945105

Chan, J. Y., Tsui, H. T., Chung, I. Y., Chan, R. Y., Kwan, Y. W., and Chan, S. W. (2014). Allicin protects rat cardiomyoblasts (H9c2 cells) from hydrogen peroxide-induced oxidative injury through inhibiting the generation of intracellular reactive oxygen species. Int. J. Food Sci. Nutr. 65, 868-873. doi: 10.3109/09637486.2014.925428

Chao, X., Zhou, J., Chen, T., Liu, W., Dong, W., Qu, Y., et al. (2010). Neuroprotective effect of osthole against acute ischemic stroke on middle cerebral ischemia occlusion in rats. Brain Res. 1363, 206-211. doi: 10.1016/j. brainres.2010.09.052

\section{AUTHOR CONTRIBUTIONS}

JS contributed as the senior author and the principal investigator (PI) of this study and refined the study. SC and HC wrote the first draft of the manuscript and contributed to the overall design. QD drew the structures of compounds. All authors read, critically reviewed, and approved the final manuscript.

\section{FUNDING}

This work was supported by the Hong Kong General Research Fund (GRF Nos. 17102915 and 17118717), the Research Grants Council, the Hong Kong SAR and Health and Medical Research Fund, the Hong Kong SAR (No. 13142901). The AoE/P-705/16 Areas of Excellence Scheme, RGC, The Hong Kong SAR; SIRI/04/04/2015/06 Shenzhen Basic Research Plan Project.

Che, N., Ma, Y., and Xin, Y. (2017). Protective role of fucoidan in cerebral ischemiareperfusion injury through inhibition of MAPK signaling pathway. Biomol. Ther. (Seoul) 25, 272-278. doi: 10.4062/biomolther.2016.098

Chehaibi, K., Trabelsi, I., Mahdouani, K., and Slimane, M. N. (2016). Correlation of oxidative stress parameters and inflammatory markers in ischemic stroke patients. J. Stroke Cerebrovasc. Dis. 25, 2585-2593. doi: 10.1016/j. jstrokecerebrovasdis.2016.06.042

Chen, H., Guan, B., Chen, X., Chen, X., Li, C., Qiu, J., et al. (2018). Baicalin attenuates blood-brain barrier disruption and hemorrhagic transformation and improves neurological outcome in ischemic stroke rats with delayed t-PA treatment: involvement of ONOO(-)-MMP-9 pathway. Transl. Stroke Res. 9, 515-529. doi: 10.1007/s12975-017-0598-3

Chen, H. S., Chen, X., Li, W. T., and Shen, J. G. (2018). Targeting RNS/caveolin1/MMP signaling cascades to protect against cerebral ischemia-reperfusion injuries: potential application for drug discovery. Acta Pharmacol. Sin. 39, 669-682. doi: 10.1038/aps.2018.27

Chen, Z., Yuan, Q., Xu, G., Chen, H., Lei, H., and Su, J. (2018). Effects of quercetin on proliferation and $\mathrm{H}(2) \mathrm{O}(2)$-induced apoptosis of intestinal porcine enterocyte cells. Molecules 23:2012. doi: 10.3390/molecules2308 2012

Chen, H., Guan, B., and Shen, J. (2016). Targeting ONOO-/HMGB1/MMP-9 signaling cascades: potential for drug development from chinese medicine to attenuate ischemic brain injury and hemorrhagic transformation induced by thrombolytic treatment. Integr. Med. Int. 3, 32-52.

Chen, H., Guan, B., Wang, B., Pu, H., Bai, X., Chen, X., et al. (2019). Glycyrrhizin prevents hemorrhagic transformation and improves neurological outcome in ischemic stroke with delayed thrombolysis through targeting peroxynitritemediated hmgb1 signaling. Transl Stroke Res. [Epub ahead of print]. doi: 10 . 1007/s12975-019-00772-1

Chen, H. S., Chen, X. M., Feng, J. H., Liu, K. J., Qi, S. H., and Shen, J. G. (2015). Peroxynitrite decomposition catalyst reduces delayed thrombolysis-induced hemorrhagic transformation in ischemia-reperfused rat brains. CNS Neurosci. Ther. 21, 585-590. doi: 10.1111/cns.12406

Chen, W., Xu, B., Xiao, A., Liu, L., Fang, X., Liu, R., et al. (2015). TRPM7 inhibitor carvacrol protects brain from neonatal hypoxic-ischemic injury. Mol. Brain 8:11. doi: 10.1186/s13041-015-0102-5

Chen, H. S., Qi, S. H., and Shen, J. G. (2017). One-compound-multi-target: combination prospect of natural compounds with thrombolytic therapy in acute ischemic stroke. Curr. Neuropharmacol. 15, 134-156. doi: 10.2174/ 1570159x14666160620102055

Chen, X. M., Chen, H. S., Xu, M. J., and Shen, J. G. (2013). Targeting reactive nitrogen species: a promising therapeutic strategy for cerebral ischemiareperfusion injury. Acta Pharmacol. Sin. 34, 67-77. doi: 10.1038/aps.2012.82

Chen, Y., Wu, X., Yu, S., Lin, X., Wu, J., Li, L., et al. (2012). Neuroprotection of tanshinone IIA against cerebral ischemia/reperfusion injury through inhibition 
of macrophage migration inhibitory factor in rats. PLoS ONE 7:e40165. doi: 10.1371/journal.pone.0040165

Cheng, C. Y., Ho, T. Y., Lee, E. J., Su, S. Y., Tang, N. Y., and Hsieh, C. L. (2008). Ferulic acid reduces cerebral infarct through its antioxidative and antiinflammatory effects following transient focal cerebral ischemia in rats. Am. J. Chin. Med. 36, 1105-1119. doi: 10.1142/S0192415X08006570

Cheng, P., Kuang, F., and Ju, G. (2016). Aescin reduces oxidative stress and provides neuroprotection in experimental traumatic spinal cord injury. Free Radic. Biol. Med. 99, 405-417. doi: 10.1016/j.freeradbiomed.2016.09.002

Cojocaru, I. M., Cojocaru, M., Iliescu, I., Botnaru, L., Gurban, C. V., Sfrijan, F., et al. (2010). Plasma myeloperoxidase levels in patients with acute ischemic stroke. Rom. J. Int. Med. 48, 101-104.

Collino, M., Aragno, M., Mastrocola, R., Benetti, E., Gallicchio, M., Dianzani, C., et al. (2006). Oxidative stress and inflammatory response evoked by transient cerebral ischemia/reperfusion: effects of the PPAR- $\alpha$ agonist WY14643. Free Radic. Biol. Med. 41, 579-589. doi: 10.1016/j.freeradbiomed.2006.04.030

Couturier, J. Y., Ding-Zhou, L., Croci, N., Plotkine, M., and Margaill, I. (2003). 3-Aminobenzamide reduces brain infarction and neutrophil infiltration after transient focal cerebral ischemia in mice. Exp. Neurol. 184, 973-980. doi: 10. 1016/S0014-4886(03)00367-4

Crack, P. J., and Taylor, J. M. (2005). Reactive oxygen species and the modulation of stroke. Free Radic. Biol. Med. 38, 1433-1444. doi: 10.1016/j.freeradbiomed. 2005.01.019

Cui, L., Zhang, X., Yang, R., Liu, L., Wang, L., Li, M., et al. (2010). Baicalein is neuroprotective in rat MCAO model: role of 12/15-lipoxygenase, mitogenactivated protein kinase and cytosolic phospholipase A2. Pharmacol. Biochem. Behav. 96, 469-475. doi: 10.1016/j.pbb.2010.07.007

Davies, M. J., Hawkins, C. L., Pattison, D. I., and Rees, M. D. (2008). Mammalian heme peroxidases: from molecular mechanisms to health implications. Antioxid. Redox. Signal. 10, 1199-1234. doi: 10.1089/ars.2007.1927

Dominguez, C., Delgado, P., Vilches, A., Martin-Gallan, P., Ribo, M., Santamarina, E., et al. (2010). Oxidative stress after thrombolysis-induced reperfusion in human stroke. Stroke 41, 653-660. doi: 10.1161/STROKEAHA.109.571935

Dou, Z., Rong, X., Zhao, E., Zhang, L., and Lv, Y. (2019). Neuroprotection of resveratrol against focal cerebral ischemia/reperfusion injury in mice through a mechanism targeting gut-brain axis. Cell Mol. Neurobiol. 39, 883-898. doi: 10.1007/s10571-019-00687-3

England, T. J., Hind, W. H., Rasid, N. A., and O'Sullivan, S. E. (2015). Cannabinoids in experimental stroke: a systematic review and meta-analysis. J. Cereb. Blood Flow Metab. 35, 348-358. doi: 10.1038/jcbfm.2014.218

Fang, L., Gao, H., Zhang, W., Zhang, W., and Wang, Y. (2015). Resveratrol alleviates nerve injury after cerebral ischemia and reperfusion in mice by inhibiting inflammation and apoptosis. Int. J. Clin. Exp. Med. 8, 3219-3226.

Feng, J., Chen, X., Guan, B., Li, C., Qiu, J., and Shen, J. (2018a). Inhibition of peroxynitrite-induced mitophagy activation attenuates cerebral ischemiareperfusion injury. Mol. Neurobiol. 55, 6369-6386. doi: 10.1007/s12035-0170859-x

Feng, J., Chen, X., Lu, S., Li, W., Yang, D., Su, W., et al. (2018b). Naringin attenuates cerebral ischemia-reperfusion injury through inhibiting peroxynitrite-mediated mitophagy activation. Mol. Neurobiol. 55, 9029-9042. doi: 10.1007/s12035-018-1027-7

Fernandes, M. Y. D., Carmo, M., Fonteles, A. A., Neves, J. C. S., Silva, A., Pereira, J. F., et al. (2019). (-)-alpha-bisabolol prevents neuronal damage and memory deficits through reduction of proinflammatory markers induced by permanent focal cerebral ischemia in mice. Eur. J. Pharmacol. 842, 270-280. doi: 10.1016/j.ejphar.2018.09.036

Ferreira Ede, O., Fernandes, M. Y., Lima, N. M., Neves, K. R., Carmo, M. R., Lima, F. A., et al. (2016). Neuroinflammatory response to experimental stroke is inhibited by eriodictyol. Behav. Brain Res. 312, 321-332. doi: 10.1016/j.bbr. 2016.06.046

Fonteles, A. A., de Souza, C. M., de Sousa Neves, J. C., Menezes, A. P., Santos do Carmo, M. R., Fernandes, F. D., et al. (2016). Rosmarinic acid prevents against memory deficits in ischemic mice. Behav. Brain Res. 297, 91-103. doi: 10.1016/j.bbr.2015.09.029

Forghani, R., Kim, H. J., Wojtkiewicz, G. R., Bure, L., Wu, Y., Hayase, M., et al. (2015). Myeloperoxidase propagates damage and is a potential therapeutic target for subacute stroke. J. Cereb. Blood Flow Metab. 35, 485-493. doi: 10. $1038 /$ jcbfm.2014.222
Fu, S., Gu, Y., Jiang, J. Q., Chen, X., Xu, M., Chen, X., et al. (2014). Calycosin-7-Obeta-D-glucoside regulates nitric oxide /caveolin-1/matrix metalloproteinases pathway and protects blood-brain barrier integrity in experimental cerebral ischemia-reperfusion injury. J. Ethnopharmacol. 155, 692-701. doi: 10.1016/j. jep.2014.06.015

Gallelli, L. (2019). Escin: a review of its anti-edematous, anti-inflammatory, and venotonic properties. Drug Des. Dev. Ther. 13, 3425-3437. doi: 10.2147/DDDT. S207720

Gasche, Y., Fujimura, M., Morita-Fujimura, Y., Copin, J. C., Kawase, M., Massengale, J., et al. (1999). Early appearance of activated matrix metalloproteinase- 9 after focal cerebral ischemia in mice: a possible role in blood-brain barrier dysfunction. J. Cereb. Blood Flow Metab. 19, 1020-1028. doi: 10.1097/00004647-199909000-00010

Gong, J., Sun, F., Li, Y., Zhou, X., Duan, Z., Duan, F., et al. (2015). Momordica charantia polysaccharides could protect against cerebral ischemia/reperfusion injury through inhibiting oxidative stress mediated c-Jun N-terminal kinase 3 signaling pathway. Neuropharmacology 91, 123-134. doi: 10.1016/j. neuropharm.2014.11.020

Granger, D. N., and Kvietys, P. R. (2015). Reperfusion injury and reactive oxygen species: the evolution of a concept. Redox Biol. 6, 524-551. doi: 10.1016/j.redox. 2015.08.020

Green, P. S., Mendez, A. J., Jacob, J. S., Crowley, J. R., Growdon, W., Hyman, B. T., et al. (2004). Neuronal expression of myeloperoxidase is increased in Alzheimer's disease. J. Neurochem. 90, 724-733. doi: 10.1111/j.1471-4159.2004. 02527.x

Gu, Y., Zheng, G., Xu, M., Li, Y., Chen, X., Zhu, W., et al. (2012). Caveolin-1 regulates nitric oxide-mediated matrix metalloproteinases activity and bloodbrain barrier permeability in focal cerebral ischemia and reperfusion injury. J. Neurochem. 120, 147-156. doi: 10.1111/j.1471-4159.2011.07542.x

Guan, W., Zhao, Y., and Xu, C. (2011). A Combined treatment with taurine and intra-arterial thrombolysis in an embolic model of stroke in rats: increased neuroprotective efficacy and extended therapeutic time window. Transl. Stroke Res.2, 80-91. doi: 10.1007/s12975-010-0050-4

Guclu-Ustundag, O., and Mazza, G. (2007). Saponins: properties, applications and processing. Crit. Rev. Food Sci. Nutr. 47, 231-258.

Guo, M., Lu, H., Qin, J., Qu, S., Wang, W., Guo, Y., et al. (2019). Biochanin a provides neuroprotection against cerebral ischemia/reperfusion injury by Nrf2mediated inhibition of oxidative stress and inflammation signaling pathway in rats. Med. Sci. Monit. 25, 8975-8983. doi: 10.12659/MSM.918665

Gursoy-Ozdemir, Y., Can, A., and Dalkara, T. (2004). Reperfusion-induced oxidative/nitrative injury to neurovascular unit after focal cerebral ischemia. Stroke 35, 1449-1453. doi: 10.1161/01.STR.0000126044.83777.f4

Hawkins, C. L., Pattison, D. I., and Davies, M. J. (2003). Hypochlorite-induced oxidation of amino acids, peptides and proteins. Amino Acids 25, 259-274. doi: 10.1007/s00726-003-0016-x

Hayakawa, K., Mishima, K., Irie, K., Hazekawa, M., Mishima, S., Fujioka, M., et al. (2008). Cannabidiol prevents a post-ischemic injury progressively induced by cerebral ischemia via a high-mobility group box1-inhibiting mechanism. Neuropharmacology 55, 1280-1286. doi: 10.1016/j.neuropharm.2008.06.040

Horvath, E., Hutanu, A., Chiriac, L., Dobreanu, M., Oradan, A., and Nagy, E. E. (2018). Ischemic damage and early inflammatory infiltration are different in the core and penumbra lesions of rat brain after transient focal cerebral ischemia. J. Neuroimmunol. 324, 35-42. doi: 10.1016/j.jneuroim.2018.08.002

Hou, Y., Wang, K., Wan, W., Cheng, Y., Pu, X., and Ye, X. (2018). Resveratrol provides neuroprotection by regulating the JAK2/STAT3/PI3K/AKT/mTOR pathway after stroke in rats. Genes Dis. 5, 245-255. doi: 10.1016/j.gendis.2018. 06.001

Hoy, A., Leininger-Muller, B., Poirier, O., Siest, G., Gautier, M., Elbaz, A., et al. (2003). Myeloperoxidase polymorphisms in brain infarction. Association with infarct size and functional outcome. Atherosclerosis 167, 223-230. doi: 10.1016/ s0021-9150(02)00041-2

Hu, X. M., Zhang, Y., and Zeng, F. D. (2004). Effects of sodium beta-aescin on expression of adhesion molecules and migration of neutrophils after middle cerebral artery occlusion in rats. Acta Pharmacol. Sin. 25, 869-875.

Huang, L., Chen, C., Zhang, X., Li, X., Chen, Z., Yang, C., et al. (2018). Neuroprotective effect of curcumin against cerebral ischemia-reperfusion via mediating autophagy and inflammation. J. Mol. Neurosci. 64, 129-139. doi: 10.1007/s12031-017-1006-x 
Huang, Q., Sun, M., Li, M., Zhang, D., Han, F., Wu, J. C., et al. (2018). Combination of $\mathrm{NAD}(+)$ and $\mathrm{NADPH}$ offers greater neuroprotection in ischemic stroke models by relieving metabolic stress. Mol. Neurobiol. 55, 6063-6075. doi: 10 . 1007/s12035-017-0809-7

Hunter, R., Caira, M., and Stellenboom, N. (2005). Thiolsulfinate allicin from garlic: inspiration for a new antimicrobial agent. Ann. N. Y. Acad. Sci. 1056, 234-241. doi: 10.1196/annals.1352.011

Hwang, Y. S., Shin, C. Y., Huh, Y., and Ryu, J. H. (2002). Hwangryun-Hae-Doktang (Huanglian-Jie-Du-Tang) extract and its constituents reduce ischemiareperfusion brain injury and neutrophil infiltration in rats. Life Sci. 71, 21052117. doi: 10.1016/s0024-3205(02)01920-3

Jang, J. W., Lee, J. K., Hur, H., Kim, T. W., Joo, S. P., and Piao, M. S. (2014). Rutin improves functional outcome via reducing the elevated matrix metalloproteinase-9 level in a photothrombotic focal ischemic model of rats. J. Neurol. Sci. 339, 75-80. doi: 10.1016/j.jns.2014.01.024

Jayaraj, R. L., Azimullah, S., Beiram, R., Jalal, F. Y., and Rosenberg, G. A. (2019). Neuroinflammation: friend and foe for ischemic stroke. J. Neuroinflamm. 16:142. doi: 10.1186/s12974-019-1516-2

Ji, H. J., Hu, J. F., Wang, Y. H., Chen, X. Y., Zhou, R., and Chen, N. H. (2010). Osthole improves chronic cerebral hypoperfusion induced cognitive deficits and neuronal damage in hippocampus. Eur. J. Pharmacol. 636, 96-101. doi: 10.1016/j.ejphar.2010.03.038

Jiang, S., Han, J., Li, T., Xin, Z., Ma, Z., Di, W., et al. (2017). Curcumin as a potential protective compound against cardiac diseases. Pharmacol. Res. 119, 373-383. doi: 10.1016/j.phrs.2017.03.001

Jiang, W. L., Tian, J. W., Fu, F. H., Zhu, H. B., and Hou, J. (2010). Neuroprotective efficacy and therapeutic window of Forsythoside B: in a rat model of cerebral ischemia and reperfusion injury. Eur. J. Pharmacol. 640, 75-81. doi: 10.1016/j. ejphar.2010.04.055

Jickling, G. C., Liu, D., Ander, B. P., Stamova, B., Zhan, X., and Sharp, F. R. (2015). Targeting neutrophils in ischemic stroke: translational insights from experimental studies. J. Cereb. Blood Flow Metab. 35, 888-901. doi: 10.1038/ jcbfm.2015.45

Jickling, G. C., Liu, D., Stamova, B., Ander, B. P., Zhan, X., Lu, A., et al. (2014). Hemorrhagic transformation after ischemic stroke in animals and humans. J. Cereb. Blood Flow Metabol. 34, 185-199. doi: 10.1038/jcbfm.2013.203

Jin, Y., Wei, F., Dai, X., Qi, M., and Ma, Y. (2018). Anti-inflammatory effect of 4methylcyclopentadecanone in rats submitted to ischemic stroke. Fundam. Clin. Pharmacol. 32, 270-278. doi: 10.1111/fcp.12348

Jing, X., Ren, D., Wei, X., Shi, H., Zhang, X., Perez, R. G., et al. (2013). Eriodictyol7-O-glucoside activates Nrf2 and protects against cerebral ischemic injury. Toxicol. Appl. Pharmacol. 273, 672-679.

Khaksar, S., and Bigdeli, M. R. (2017). Correlation between cannabidiol-induced reduction of infarct volume and inflammatory factors expression in ischemic stroke model. Basic Clin. Neurosci. 8, 139-146. doi: 10.18869/nirp.bcn.8.2.139

Khan, M. M., Ahmad, A., Ishrat, T., Khuwaja, G., Srivastawa, P., Khan, M. B., et al. (2009). Rutin protects the neural damage induced by transient focal ischemia in rats. Brain Res. 1292, 123-135. doi: 10.1016/j.brainres.2009.07.026

Khan, M. M., Motto, D. G., Lentz, S. R., and Chauhan, A. K. (2012). ADAMTS13 reduces VWF-mediated acute inflammation following focal cerebral ischemia in mice. J. Thromb. Haemost. 10, 1665-1671. doi: 10.1111/j.1538-7836.2012. 04822.x

Kim, H., Wei, Y., Lee, J. Y., Wu, Y., Zheng, Y., Moskowitz, M. A., et al. (2016). Myeloperoxidase inhibition increases neurogenesis after ischemic stroke. J. Pharmacol. Exp. Ther. 359, 262-272. doi: 10.1124/jpet.116.235127

Kim, H. J., Wei, Y., Wojtkiewicz, G. R., Lee, J. Y., Moskowitz, M. A., and Chen, J. W. (2018). Reducing myeloperoxidase activity decreases inflammation and increases cellular protection in ischemic stroke. J. Cereb. Blood Flow Metab. doi: 10.1177/0271678X18771978

Kim, H. J., Wei, Y., Wojtkiewicz, G. R., Lee, J. Y., Moskowitz, M. A., and Chen, J. W. (2019). Reducing myeloperoxidase activity decreases inflammation and increases cellular protection in ischemic stroke. J. Cereb. Blood Flow Metab. 39, 1864-1877. doi: 10.1177/0271678X18771978

Kiss, T., Balasubramanian, P., Valcarcel-Ares, M. N., Tarantini, S., Yabluchanskiy, A., Csipo, T., et al. (2019a). Nicotinamide mononucleotide (NMN) treatment attenuates oxidative stress and rescues angiogenic capacity in aged cerebromicrovascular endothelial cells: a potential mechanism for the prevention of vascular cognitive impairment. Geroscience 41, 619-630. doi: 10.1007/s11357-019-00074-2

Kiss, T., Giles, C. B., Tarantini, S., Yabluchanskiy, A., Balasubramanian, P., Gautam, T., et al. (2019b). Nicotinamide mononucleotide (NMN) supplementation promotes anti-aging miRNA expression profile in the aorta of aged mice, predicting epigenetic rejuvenation and anti-atherogenic effects. Geroscience 41, 419-439. doi: 10.1007/s11357-019-00095-X

Kong, L. L., Wang, Z. Y., Han, N., Zhuang, X. M., Wang, Z. Z., Li, H., et al. (2014). Neutralization of chemokine-like factor 1, a novel C-C chemokine, protects against focal cerebral ischemia by inhibiting neutrophil infiltration via MAPK pathways in rats. J. Neuroinflamm. 11, 112. doi: 10.1186/1742-209411-112

Kunnumakkara, A. B., Bordoloi, D., Harsha, C., Banik, K., Gupta, S. C., and Aggarwal, B. B. (2017). Curcumin mediates anticancer effects by modulating multiple cell signaling pathways. Clin. Sci. (Lond.) 131, 1781-1799. doi: 10.1042/ CS20160935

Lees, K. R., Zivin, J. A., Ashwood, T., Davalos, A., Davis, S. M., Diener, H. C., et al. (2006). NXY-059 for acute ischemic stroke. N. Engl. J. Med. 354, 588-600.

Lei, J., and Chen, Q. (2018). Resveratrol attenuates brain damage in permanent focal cerebral ischemia via activation of PI3K/Akt signaling pathway in rats. Neurol. Res. 40, 1014-1020. doi: 10.1080/01616412.2018.1509826

Lei, J. R., Tu, X. K., Wang, Y., Tu, D. W., and Shi, S. S. (2019). Resveratrol downregulates the TLR4 signaling pathway to reduce brain damage in a rat model of focal cerebral ischemia. Exp. Ther. Med. 17, 3215-3221. doi: 10.3892/ etm.2019.7324

Li, C., Yan, Z., Yang, J., Chen, H., Li, H., Jiang, Y., et al. (2010). Neuroprotective effects of resveratrol on ischemic injury mediated by modulating the release of neurotransmitter and neuromodulator in rats. Neurochem. Int. 56, 495-500. doi: 10.1016/j.neuint.2009.12.009

Li, H. Y., Yuan, Z. Y., Wang, Y. G., Wan, H. J., Hu, J., Chai, Y. S., et al. (2012). Role of baicalin in regulating Toll-like receptor $2 / 4$ after ischemic neuronal injury. Chin. Med. J. 125, 1586-1593.

Li, M., Qu, Y. Z., Zhao, Z. W., Wu, S. X., Liu, Y. Y., Wei, X. Y., et al. (2012). Astragaloside IV protects against focal cerebral ischemia/reperfusion injury correlating to suppression of neutrophils adhesion-related molecules. Neurochem. Int. 60, 458-465. doi: 10.1016/j.neuint.2012.01.026

Li, Q., Ren, F. Q., Yang, C. L., Zhou, L. M., Liu, Y. Y., Xiao, J., et al. (2015). Antiproliferation effects of isorhamnetin on lung cancer cells in vitro and in vivo. Asian Pac. J. Cancer Prev. 16, 3035-3042. doi: 10.7314/apjcp.2015.16.7.3035

Li, S., Sun, X., Xu, L., Sun, R., Ma, Z., Deng, X., et al. (2017). Baicalin attenuates in vivo and in vitro hyperglycemia-exacerbated ischemia/reperfusion injury by regulating mitochondrial function in a manner dependent on AMPK. Eur. J. Pharmacol. 815, 118-126. doi: 10.1016/j.ejphar.2017.07.041

Li, W., Chen, Z., Yan, M., He, P., Chen, Z., and Dai, H. (2016a). The protective role of isorhamnetin on human brain microvascular endothelial cells from cytotoxicity induced by methylglyoxal and oxygen-glucose deprivation. J. Neurochem. 136, 651-659. doi: 10.1111/jnc.13436

Li, Y., Yao, J., Han, C., Yang, J., Chaudhry, M. T., Wang, S., et al. (2016b). Quercetin. Inflamm. Immun. Nutr. 8:167.

Li, Z., Fang, F., Wang, Y., and Wang, L. (2016a). Resveratrol protects CA1 neurons against focal cerebral ischemic reperfusion-induced damage via the ERK-CREB signaling pathway in rats. Pharmacol. Biochem. Behav. 14, 21-27. doi: 10.1016/ j.pbb.2016.04.007

Li, Z., Hua, C., Pan, X., Fu, X., and Wu, W. (2016b). Carvacrol exerts neuroprotective effects via suppression of the inflammatory response in middle cerebral artery occlusion rats. Inflammation 39, 1566-1572. doi: 10.1007/ s10753-016-0392-5

Liang, W., Huang, X., and Chen, W. (2017). The effects of baicalin and baicalein on cerebral ischemia: a review. Aging Dis. 8, 850-867. doi: 10.14336/AD.2017.0829

Liu, L., Zhang, X., Wang, L., Yang, R., Cui, L., Li, M., et al. (2010). The neuroprotective effects of Tanshinone IIA are associated with induced nuclear translocation of TORC1 and upregulated expression of TORC1, pCREB and BDNF in the acute stage of ischemic stroke. Brain Res. Bull. 82, 228-233. doi: 10.1016/j.brainresbull.2010.04.005

Liu, M., Yin, Y., Ye, X., Zeng, M., Zhao, Q., Keefe, D. L., et al. (2013). Resveratrol protects against age-associated infertility in mice. Hum. Reprod. 28, 707-717. doi: 10.1093/humrep/des437 
Liu, W., Hendren, J., Qin, X. J., Shen, J., and Liu, K. J. (2009). Normobaric hyperoxia attenuates early blood-brain barrier disruption by inhibiting MMP9-mediated occludin degradation in focal cerebral ischemia. J. Neurochem. 108, 811-820. doi: 10.1111/j.1471-4159.2008.05821.x

Liu, X., Wang, T., Liu, X., Cai, L., Qi, J., Zhang, P., et al. (2016). Biochanin A protects lipopolysaccharide/D-galactosamine-induced acute liver injury in mice by activating the Nrf2 pathway and inhibiting NLRP3 inflammasome activation. Int. Immunopharmacol. 38, 324-331. doi: 10.1016/j.intimp.2016.06. 009

Liu, Y., Tong, L., Luo, Y., Li, X., Chen, G., and Wang, Y. (2018). Resveratrol inhibits the proliferation and induces the apoptosis in ovarian cancer cells via inhibiting glycolysis and targeting AMPK/mTOR signaling pathway. J. Cell. Biochem. 119, 6162-6172. doi: 10.1002/jcb.26822

Liu, Z., Ran, Y., Huang, S., Wen, S., Zhang, W., Liu, X., et al. (2017). Curcumin protects against ischemic stroke by titrating microglia/macrophage polarization. Front. Aging Neurosci. 9:233. doi: 10.3389/fnagi.2017.00233

Luan, H., Kan, Z., Xu, Y., Lv, C., and Jiang, W. (2013). Rosmarinic acid protects against experimental diabetes with cerebral ischemia: relation to inflammation response. J. Neuroinflamm.10:28. doi: 10.1186/1742-2094-10-28

Ma, X. J., Cheng, J. W., Zhang, J., Liu, A. J., Liu, W., Guo, W., et al. (2012). Eselectin deficiency attenuates brain ischemia in mice. CNS Neurosci. Ther. 18, 903-908. doi: 10.1111/cns.12000

Manso, H., Krug, T., Sobral, J., Albergaria, I., Gaspar, G., Ferro, J. M., et al. (2011). Variants in the inflammatory IL6 and MPO genes modulate stroke susceptibility through main effects and gene-gene interactions. J. Cereb. Blood Flow Metab. 31, 1751-1759. doi: 10.1038/jcbfm.2011.27

Mao, X., Yin, W., Liu, M., Ye, M., Liu, P., Liu, J., et al. (2011). Osthole, a natural coumarin, improves neurobehavioral functions and reduces infarct volume and matrix metalloproteinase- 9 activity after transient focal cerebral ischemia in rats. Brain Res. 1385, 275-280. doi: 10.1016/j.brainres.2011.02.015

Marquez, L. A., and Dunford, H. B. (1994). Chlorination of taurine by myeloperoxidase. Kinetic evidence for an enzyme-bound intermediate. J. Biol. Chem. 269, 7950-7956.

Matsuo, Y., Onodera, H., Shiga, Y., Nakamura, M., Ninomiya, M., Kihara, T., et al. (1994). Correlation between myeloperoxidase-quantified neutrophil accumulation and ischemic brain injury in the rat. Effects of neutrophil depletion. Stroke 25, 1469-1475. doi: 10.1161/01.str.25.7.1469

Menon, V. P., and Sudheer, A. R. (2007). Antioxidant and anti-inflammatory properties of curcumin. Adv. Exp. Med. Biol. 595, 105-125.

Mishima, K., Hayakawa, K., Abe, K., Ikeda, T., Egashira, N., Iwasaki, K., et al. (2005). Cannabidiol prevents cerebral infarction via a serotonergic 5hydroxytryptamine1A receptor-dependent mechanism. Stroke 36, 1077-1082. doi: 10.1161/01.STR.0000163083.59201.34

Mishra, P., Kale, R. K., and Kar, A. (2008). Chemoprevention of mammary tumorigenesis and chemomodulation of the antioxidative enzymes and peroxidative damage in prepubertal Sprague Dawley rats by Biochanin A. Mol. Cell. Biochem. 312, 1-9. doi: 10.1007/s11010-008-9714-8

Mizuma, A., and Yenari, M. A. (2017). Anti-inflammatory targets for the treatment of reperfusion injury in stroke. Front. Neurol. 8:467. doi: 10.3389/fneur.2017. 00467

Mosawy, S., Jackson, D. E., Woodman, O. L., and Linden, M. D. (2013). Inhibition of platelet-mediated arterial thrombosis and platelet granule exocytosis by 3',4'dihydroxyflavonol and quercetin. Platelets 24, 594-604. doi: 10.3109/09537104. 2012.749396

Muir, S. W., Harrow, C., Dawson, J., Lees, K. R., Weir, C. J., Sattar, N., et al. (2008). Allopurinol use yields potentially beneficial effects on inflammatory indices in those with recent ischemic stroke: a randomized, double-blind, placebo-controlled trial. Stroke 39, 3303-3307. doi: 10.1161/STROKEAHA.108. 519793

Nagra, R. M., Becher, B., Tourtellotte, W. W., Antel, J. P., Gold, D., Paladino, T., et al. (1997). Immunohistochemical and genetic evidence of myeloperoxidase involvement in multiple sclerosis. J. Neuroimmunol. 78, 97-107. doi: 10.1016/s0165-5728(97)00089-1

Nakase, T., Yoshioka, S., and Suzuki, A. (2011). Free radical scavenger, edaravone, reduces the lesion size of lacunar infarction in human brain ischemic stroke. BMC Neurol. 11:39. doi: 10.1186/1471-2377-11-39

Nussbaum, C., Klinke, A., Adam, M., Baldus, S., and Sperandio, M. (2013). Myeloperoxidase: a leukocyte-derived protagonist of inflammation and cardiovascular disease. Antioxid. Redox. Signal. 18, 692-713. doi: 10.1089/ars. 2012.4783

Palm, F., Pussinen, P. J., Safer, A., Tervahartiala, T., Sorsa, T., Urbanek, C., et al. (2018). Serum matrix metalloproteinase-8, tissue inhibitor of metalloproteinase and myeloperoxidase in ischemic stroke. Atherosclerosis 271,9-14. doi: 10.1016/ j.atherosclerosis.2018.02.012

Panasenko, O. M. (1997). The mechanism of the hypochlorite-induced lipid peroxidation. Biofactors 6, 181-190. doi: 10.1002/biof.5520060212

Pandey, A. K., Bhattacharya, P., Shukla, S. C., Paul, S., and Patnaik, R. (2015). Resveratrol inhibits matrix metalloproteinases to attenuate neuronal damage in cerebral ischemia: a molecular docking study exploring possible neuroprotection. Neural Regener. Res. 10, 568-575. doi: 10.4103/1673-5374. 278561

Park, D. J., Shah, F. A., and Koh, P. O. (2018). Quercetin attenuates neuronal cells damage in a middle cerebral artery occlusion animal model. J. Vet. Med. Sci. 80, 676-683. doi: 10.1292/jvms.17-0693

Pattison, D. I., Hawkins, C. L., and Davies, M. J. (2003). Hypochlorous acid-mediated oxidation of lipid components and antioxidants present in low-density lipoproteins: absolute rate constants, product analysis, and computational modeling. Chem. Res. Toxicol. 16, 439-449. doi: 10.1021/ tx025670s

Peng, T., Chen, X., Gao, L., Zhang, T., Wang, W., Shen, J., et al. (2016). A rationally designed rhodamine-based fluorescent probe for molecular imaging of peroxynitrite in live cells and tissues. Chem. Sci. 7, 54075413. doi: 10.1039/c6sc00012f

Peng, T., Wong, N. K., Chen, X., Chan, Y. K., Sun, Z., Hu, J. J., et al. (2014). Molecular imaging of peroxynitrite with HKGreen-4 in live cells and tissues. J. Am. Chem. Soc. 136, 11728-11734. doi: 10.1021/jacs.7b13132

Popa-Wagner, A., Hermann, D., and Gresita, A. (2019). Genetic conversion of proliferative astroglia into neurons after cerebral ischemia: a new therapeutic tool for the aged brain? Geroscience 41, 363-368. doi: 10.1007/s11357-01900136-5

Pravalika, K., Sarmah, D., Kaur, H., Vats, K., Saraf, J., Wanve, M., et al. (2019). Trigonelline therapy confers neuroprotection by reduced glutathione mediated myeloperoxidase expression in animal model of ischemic stroke. Life Sci. 216, 49-58. doi: 10.1016/j.lfs.2018.11.014

Prutz, W. A. (1996). Hypochlorous acid interactions with thiols, nucleotides DNA, and other biological substrates. Arch. Biochem. Biophys. 332, 110-120. doi: 10.1006/abbi.1996.0322

Ramos-Fernandez, M., Bellolio, M. F., and Stead, L. G. (2011). Matrix metalloproteinase-9 as a marker for acute ischemic stroke: a systematic review. J. Stroke Cerebrovasc. Dis. 20, 47-54. doi: 10.1016/j.jstrokecerebrovasdis.2009. 10.008

Reiche, E. M. V., Gelinksi, J. R., Alfieri, D. F., Flauzino, T., Lehmann, M. F., de Araujo, M. C. M., et al. (2019). Immune-inflammatory, oxidative stress and biochemical biomarkers predict short-term acute ischemic stroke death. Metab. Brain Dis. 34, 789-804. doi: 10.1007/s11011-019-00403-6

Rodrigo, R., Fernández-Gajardo, R., Gutiérrez, R., Manuel Matamala, J., Carrasco, R., Miranda-Merchak, A., et al. (2013). Oxidative stress and pathophysiology of ischemic stroke: novel therapeutic opportunities. CNS Neurol. Disord. Drug Targets 12, 698-714. doi: 10.2174/187152731131205 0015

Rosell, A., Cuadrado, E., Ortega-Aznar, A., Hernandez-Guillamon, M., Lo, E. H., and Montaner, J. (2008). MMP-9-positive neutrophil infiltration is associated to blood-brain barrier breakdown and basal lamina type IV collagen degradation during hemorrhagic transformation after human ischemic stroke. Stroke 39, 1121-1126. doi: 10.1161/STROKEAHA.107.500868

Sampaio, T. L., Menezes, R. R., da Costa, M. F., Meneses, G. C., Arrieta, M. C., Chaves Filho, A. J., et al. (2016). Nephroprotective effects of (-)-alpha-bisabolol against ischemic-reperfusion acute kidney injury. Phytomedicine 23, 18431852. doi: 10.1016/j.phymed.2016.11.008

Schraufstatter, I. U., Browne, K., Harris, A., Hyslop, P. A., Jackson, J. H., Quehenberger, O., et al. (1990). Mechanisms of hypochlorite injury of target cells. J. Clin. Invest. 85, 554-562. doi: 10.1172/JCI114472

Shen, J., Ma, S., Chan, P., Lee, W., Fung, P. C., Cheung, R. T., et al. (2006). Nitric oxide down-regulates caveolin-1 expression in rat brains during focal cerebral ischemia and reperfusion injury. J. Neurochem. 96, 1078-1089. doi: 10.1111/j.1471-4159.2005.03589.x 
Sun, M. S., Jin, H., Sun, X., Huang, S., Zhang, F. L., Guo, Z. N., et al. (2018). Free radical damage in ischemia-reperfusion injury: an obstacle in acute ischemic stroke after revascularization therapy. Oxid. Med. Cell Longev. 2018, 3804979. doi: 10.1155/2018/3804979

Suzuki, A., Yamamoto, M., Jokura, H., Fujii, A., Tokimitsu, I., Hase, T., et al. (2007). Ferulic acid restores endothelium-dependent vasodilation in aortas of spontaneously hypertensive rats. Am. J. Hypertens. 20, 508-513. doi: 10.1016/j. amjhyper.2006.11.008

Tang, C., Xue, H., Bai, C., Fu, R., and Wu, A. (2010). The effects of Tanshinone IIA on blood-brain barrier and brain edema after transient middle cerebral artery occlusion in rats. Phytomedicine 17, 1145-1149. doi: 10.1016/j.phymed.2010.03. 017

Tang, N. Y., Liu, C. H., Hsieh, C. T., and Hsieh, C. L. (2010). The anti-inflammatory effect of paeoniflorin on cerebral infarction induced by ischemia-reperfusion injury in Sprague-Dawley rats. Am. J. Chin. Med. 38, 51-64. doi: 10.1142/ S0192415X10007786

Tay, A., Tamam, Y., Yokus, B., Ustundag, M., and Orak, M. (2015). Serum myeloperoxidase levels in predicting the severity of stroke and mortality in acute ischemic stroke patients. Eur. Rev. Med. Pharmacol. Sci. 19, 1983-1988.

Tu, X. K., Yang, W. Z., Chen, J. P., Chen, Y., Chen, Q., Chen, P. P., et al. (2015). Repetitive ischemic preconditioning attenuates inflammatory reaction and brain damage after focal cerebral ischemia in rats: involvement of PI3K/Akt and ERK1/2 signaling pathway. J. Mol. Neurosci. 55, 912-922. doi: 10.1007/ s12031-014-0446-9

Tu, X. K., Yang, W. Z., Chen, J. P., Chen, Y., Ouyang, L. Q., Xu, Y. C., et al. (2014). Curcumin inhibits TLR2/4-NF-kappaB signaling pathway and attenuates brain damage in permanent focal cerebral ischemia in rats. Inflammation 37, 15441551. doi: 10.1007/s10753-014-9881-6

Tu, X. K., Yang, W. Z., Liang, R. S., Shi, S. S., Chen, J. P., Chen, C. M., et al. (2011a). Effect of baicalin on matrix metalloproteinase- 9 expression and blood-brain barrier permeability following focal cerebral ischemia in rats. Neurochem. Res. 36, 2022-2028. doi: 10.1007/s11064-011-0526-y

Tu, X. K., Yang, W. Z., Shi, S. S., Chen, Y., Wang, C. H., Chen, C. M., et al. (2011b). Baicalin inhibits TLR2/4 signaling pathway in rat brain following permanent cerebral ischemia. Inflammation 34, 463-470. doi: 10.1007/s10753-010-9254-8

Tu, X. K., Yang, W. Z., Shi, S. S., Wang, C. H., and Chen, C. M. (2009). Neuroprotective effect of baicalin in a rat model of permanent focal cerebral ischemia. Neurochem. Res. 34, 1626-1634. doi: 10.1007/s11064-009-9953-4

Tu, X. K., Zhang, H. B., Shi, S. S., Liang, R. S., Wang, C. H., Chen, C. M., et al. (2016). 5-LOX inhibitor zileuton reduces inflammatory reaction and ischemic brain damage through the activation of PI3K/Akt signaling pathway. Neurochem. Res. 41, 2779-2787. doi: 10.1007/s11064-016-1994-x

Tziomalos, K., Katrini, K., Papagianni, M., Christou, K., Gkolfinopoulou, C., Angelopoulou, S. M., et al. (2019). Impaired antioxidative activity of highdensity lipoprotein is associated with more severe acute ischemic stroke. Metabolism 98, 49-52. doi: 10.1016/j.metabol.2019.06.004

Ullen, A., Singewald, E., Konya, V., Fauler, G., Reicher, H., Nusshold, C., et al. (2013). Myeloperoxidase-derived oxidants induce blood-brain barrier dysfunction in vitro and in vivo. PLOS ONE 8:e64034. doi: 10.1371/journal.pone. 0064034

Vandooren, J., Van Damme, J., and Opdenakker, G. (2014). On the structure and functions of gelatinase B/matrix metalloproteinase- 9 in neuroinflammation. Prog. Brain Res. 214, 193-206. doi: 10.1016/B978-0-444-63486-3.00009-8

Wang, Q., Xu, J., Rottinghaus, G. E., Simonyi, A., Lubahn, D., Sun, G. Y., et al. (2002). Resveratrol protects against global cerebral ischemic injury in gerbils. Brain Res. 958, 439-447. doi: 10.1016/s0006-8993(02)03543-6

Wang, W., Tang, L., Li, Y., and Wang, Y. (2015). Biochanin A protects against focal cerebral ischemia/reperfusion in rats via inhibition of p38-mediated inflammatory responses. J. Neurol. Sci. 348, 121-125. doi: 10.1016/j.jns.2014. 11.018

Wardlaw, J. M., Murray, V., Berge, E., Del Zoppo, G., Sandercock, P., Lindley, R. L., et al. (2012). Recombinant tissue plasminogen activator for acute ischaemic stroke: an updated systematic review and meta-analysis. Lancet 379, 2364-2372. doi: 10.1016/S0140-6736(12)60738-7

Wei, H., Wang, S., Zhen, L., Yang, Q., Wu, Z., Lei, X., et al. (2015). Resveratrol attenuates the blood-brain barrier dysfunction by regulation of the MMP9/TIMP-1 balance after cerebral ischemia reperfusion in rats. J. Mol. Neurosci. MN 55, 872-879. doi: 10.1007/s12031-014-0441-1
Weiss, S. J., Klein, R., Slivka, A., and Wei, M. (1982). Chlorination of taurine by human neutrophils. Evidence for hypochlorous acid generation. J. Clin. Invest. 70, 598-607. doi: 10.1172/jci110652

Wiedenhoeft, T., Tarantini, S., Nyul-Toth, A., Yabluchanskiy, A., Csipo, T., Balasubramanian, P., et al. (2019). Fusogenic liposomes effectively deliver resveratrol to the cerebral microcirculation and improve endotheliumdependent neurovascular coupling responses in aged mice. Geroscience 41, 711-725. doi: 10.1007/s11357-019-00102-1

Wu, C. F., Hong, C., Klauck, S. M., Lin, Y. L., and Efferth, T. (2015). Molecular mechanisms of rosmarinic acid from Salvia miltiorrhiza in acute lymphoblastic leukemia cells. J. Ethnopharmacol. 176, 55-68. doi: 10.1016/j.jep.2015. 10.020

Wu, L., Li, J., Liu, T., Li, S., Feng, J., Yu, Q., et al. (2019). Quercetin shows antitumor effect in hepatocellular carcinoma LM3 cells by abrogating JAK2/STAT3 signaling pathway. Cancer Med. 8, 4806-4820. doi: 10.1002/cam4.2388

Wu, X. J., Zhou, X. B., Chen, C., and Mao, W. (2019). Systematic investigation of quercetin for treating cardiovascular disease based on network pharmacology. Comb. Chem. High. Throughput. Screen 22, 411-420. doi: 10. 2174/1386207322666190717124507

Xu, J., Xie, Z., Reece, R., Pimental, D., and Zou, M. H. (2006). Uncoupling of endothelial nitric oxidase synthase by hypochlorous acid: role of $\mathrm{NAD}(\mathrm{P}) \mathrm{H}$ oxidase-derived superoxide and peroxynitrite. Arterioscler. Thromb. Vasc. Biol. 26, 2688-2695. doi: 10.1161/01.ATV.0000249394.94588.82

Xu, M., Chen, X., Gu, Y., Peng, T., Yang, D., Chang, R. C., et al. (2013). Baicalin can scavenge peroxynitrite and ameliorate endogenous peroxynitrite-mediated neurotoxicity in cerebral ischemia-reperfusion injury. J. Ethnopharmacol. 150, 116-124. doi: 10.1016/j.jep.2013.08.020

Xue, X., Qu, X. J., Yang, Y., Sheng, X. H., Cheng, F., Jiang, E. N., et al. (2010). Baicalin attenuates focal cerebral ischemic reperfusion injury through inhibition of nuclear factor kappaB p65 activation. Biochem. Biophys. Res. Commun. 403, 398-404. doi: 10.1016/j.bbrc.2010.11.042

Yang, C., Hawkins, K. E., Dore, S., and Candelario-Jalil, E. (2019). Neuroinflammatory mechanisms of blood-brain barrier damage in ischemic stroke. Am. J. Physiol. Cell Physiol. 316, C135-C153. doi: 10.1152/ajpcell.00136.2018

Yang, Q., Huang, Q., Hu, Z., and Tang, X. (2019). Potential neuroprotective treatment of stroke: targeting excitotoxicity. Oxidat. Stress Inflamm. Front. Neurosci. 13:1036. doi: 10.3389/fnins.2019.01036

Yang, S., Wang, H., Yang, Y., Wang, R., Wang, Y., Wu, C., et al. (2019). Baicalein administered in the subacute phase ameliorates ischemia-reperfusion-induced brain injury by reducing neuroinflammation and neuronal damage. Biomed. Pharmacother. 117:109102. doi: 10.1016/j.biopha.2019.109102

Yang, X. Y., Jiang, S. Q., Zhang, L., Liu, Q. N., and Gong, P. L. (2007). Inhibitory effect of dauricine on inflammatory process following focal cerebral ischemia/reperfusion in rats. Am. J. Chin. Med. 35, 477-486. doi: 10.1142/ S0192415X07004990

Yang, Y., Estrada, E. Y., Thompson, J. F., Liu, W., and Rosenberg, G. A. (2007). Matrix metalloproteinase-mediated disruption of tight junction proteins in cerebral vessels is reversed by synthetic matrix metalloproteinase inhibitor in focal ischemia in rat. J. Cereb. Blood Flow Metab. 27, 697-709. doi: 10.1038/sj. jcbfm.9600375

Yap, Y. W., Whiteman, M., and Cheung, N. S. (2007). Chlorinative stress: an under appreciated mediator of neurodegeneration? Cell Signal. 19, 219-228. doi: 10.1016/j.cellsig.2006.06.013

Ying, W., Wei, G., Wang, D., Wang, Q., Tang, X., Shi, J., et al. (2007). Intranasal administration with $\mathrm{NAD}+$ profoundly decreases brain injury in a rat model of transient focal ischemia. Front. Biosci. 12:2728-2734. doi: 10.2741/ 2267 doi: $10.2741 / 2267$

Yu, C., He, Q., Zheng, J., Li, L. Y., Hou, Y. H., and Song, F. Z. (2017). Sulforaphane improves outcomes and slows cerebral ischemic/reperfusion injury via inhibition of NLRP3 inflammasome activation in rats. Int. Immunopharmacol. 45, 74-78. doi: 10.1016/j.intimp.2017.01.034

Yu, G., Liang, Y., Huang, Z., Jones, D. W., Pritchard, K. A. Jr., et al. (2016). Inhibition of myeloperoxidase oxidant production by $\mathrm{N}$-acetyl lysyltyrosylcysteine amide reduces brain damage in a murine model of stroke. J. Neuroinflamm. 13, 119. doi: 10.1186/s12974-016-0639-y

Yu, G., Liang, Y., Zheng, S., and Zhang, H. (2018). Inhibition of myeloperoxidase by $\mathrm{N}$-Acetyl lysyltyrosylcysteine amide reduces oxidative stress-mediated 
inflammation. neuronal damage, and neural stem cell injury in a murine model of stroke. J. Pharmacol. Exp. Ther. 364, 311-322. doi: 10.1124/jpet.117.245688

Yu, H., Zhang, Z. L., Chen, J., Pei, A., Hua, F., Qian, X., et al. (2012). Carvacrol, a food-additive, provides neuroprotection on focal cerebral ischemia/reperfusion injury in mice. PLoS ONE 7:e33584. doi: 10.1371/journal.pone.003 3584 doi: 10.1371/journal.pone.0033584

Zhang, B., Li, F., Zhao, W., Li, J., Li, Q., and Wang, W. (2015). Protective effects of allicin against ischemic stroke in a rat model of middle cerebral artery occlusion. Mol. Med. Rep. 12, 3734-3738. doi: 10.3892/mmr.2015.3883

Zhang, H., Ray, A., Miller, N. M., Hartwig, D., Pritchard, K. A., and Dittel, B. N. (2016). Inhibition of myeloperoxidase at the peak of experimental autoimmune encephalomyelitis restores blood-brain barrier integrity and ameliorates disease severity. J. Neurochem. 136, 826-836. doi: 10.1111/jnc.13426

Zhang, Y., Talalay, P., Cho, C. G., and Posner, G. H. (1992). A major inducer of anticarcinogenic protective enzymes from broccoli: isolation and elucidation of structure. Proc. Natl. Acad. Sci. U.S.A. 89, 2399-2403. doi: 10.1073/pnas.89.6. 2399

Zhao, J. J., Song, J. Q., Pan, S. Y., and Wang, K. (2016). Treatment with isorhamnetin protects the brain against ischemic injury in mice. Neurochem. Res. 41, 1939-1948. doi: 10.1007/s11064-016-1904-2

Zhao, S., Park, C. H., Li, X., Kim, Y. B., Yang, J., Sung, G. B., et al. (2015). Accumulation of rutin and betulinic acid and expression of phenylpropanoid and triterpenoid biosynthetic genes in mulberry (Morus alba L.). J. Agric. Food Chem. 63, 8622-8630. doi: 10.1021/acs.jafc.5b03221
Zhou, F., Wang, M., Ju, J., Wang, Y., Liu, Z., Zhao, X., et al. (2019). Schizandrin A protects against cerebral ischemia-reperfusion injury by suppressing inflammation and oxidative stress and regulating the AMPK/Nrf2 pathway regulation. Am. J. Transl. Res. 11, 199-209.

Zhou, X., Yang, J., Zhou, M., Zhang, Y., Liu, Y., Hou, P., et al. (2019). Resveratrol attenuates endothelial oxidative injury by inducing autophagy via the activation of transcription factor EB. Nutr. Metab. (Lond.) 16, 42. doi: 10.1186/s12986019-0371-6

Zhou, Y. F., Li, W. T., Han, H. C., Gao, D. K., He, X. S., Li, L., et al. (2014). Allicin protects rat cortical neurons against mechanical trauma injury by regulating nitric oxide synthase pathways. Brain Res. Bull. 100, 14-21. doi: 10.1016/j. brainresbull.2013.10.013

Conflict of Interest: The authors declare that the research was conducted in the absence of any commercial or financial relationships that could be construed as a potential conflict of interest.

Copyright (c) 2020 Chen, Chen, Du and Shen. This is an open-access article distributed under the terms of the Creative Commons Attribution License (CC BY). The use, distribution or reproduction in other forums is permitted, provided the original author(s) and the copyright owner(s) are credited and that the original publication in this journal is cited, in accordance with accepted academic practice. No use, distribution or reproduction is permitted which does not comply with these terms. 